\title{
REFORM OF THE FEDERAL CRIMINAL LAWS: ISSUES, TACTICS AND PROSPECTS
}

\author{
LOUIS B. SCHWARTZ*
}

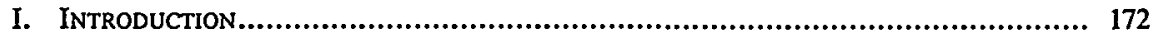

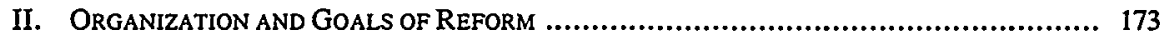

A. Organization for Reform ................................................................... 173

B. Basic Policy: Deterrence; Role of Retribution ........................................ 182

III. SOME Common GRound: ConSENSUS ReformS .............................................. 184

A. Basic Structure of the Code; Federal Jurisdiction ....................................... 184

B. Modernized Definition of Offenses ......................................................... 190

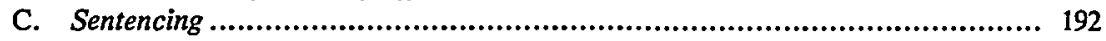

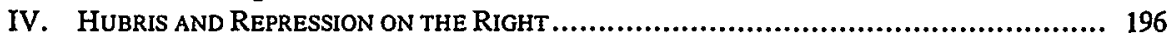

A. The "Official Secrets" Provisions ...................................................... 197

B. Abolishing the Insanity Defense ........................................................... 199

C. Harsh Sentencing ............................................................................. 200

D. Wiretapping .................................................................................. 207

E. Entrapment ................................................................................ 208

F. Public Safety Orders; Riots ................................................................ 209

G. Miscellaneous ................................................................................... 210

V. FlatUlenCE ON THE LeFT; THE RhETORIC OF OPPOSITION................................. 210

A. Mistake of Law; Superior Orders; the "Ehrlichman Defense" ........................ 213

B. Repression of Political Dissent .............................................................. 217

C. Disorderly Conduct and Assimilated Offenses .......................................... 219

D. Anti-Libertarian Proposals from the Left .................................................. 220

E. Compromise Rejected: Snatching Defeat from the Jaws of Victory................... 220

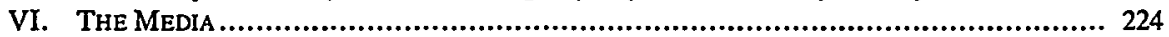

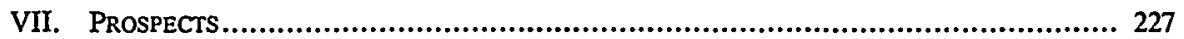

* Benjamin Franklin Professor of Law, University of Pennsylvania; Director, National Commission on Reform of Federal Criminal Laws.

THE FOLLOWING CITATIONS WILL BE USED IN THIS ARTICLE:

S. I, 93d Cong., 2d Sess. (1974) [hereinafter cited as S. I];

National Commission on Reform of Federal Criminal laws, Final Report (1971) [hereinafter cited as COMMISSION FINAL REPORT];

National Commission on Reform of Federal Criminal Laws, Study Draft of a New Federal CRIMINal Code (1970) [hereinafter cited as STUdY DRAFT];

National Commission on Reform of Federal Criminal Laws, Working Papers (1970) [hereinafter cited as COMMISSION WORKING PAPERS];

Proposed New Federal Criminal Code, in National Commission on Reform of Federal Criminal Laws, Final Report (1971) [hereinafter cited as Commission CODE];

Staff of Senate Comm. on the Judiciary, 93D Cong., 2D Sess., Report on the Criminal. Justice Codification, Revision, and Reform ACt of 1974 (Comm. Print 1974) [hereinafter cited as SUBCOMMITTEE REPORT];

Hearings on Reform of the Federal Criminal Laws Before the Subcomm. on Criminal Laws and Procedures of the Senate Comm. on the Judiciary, 92d Cong., 1st Sess. through 94th Cong., 1st Sess. (1971-75) [hereinafter cited as Subcommirtee Hearings]. 


\section{INTRODUCTION}

Reform of the federal criminal law is a project of awesome scope and complexity entailing not merely legal considerations but also sensitivity to history, politics, social psychology, penology and the religious, ethnic and economic tensions within this nation. The reform project must conform with that remarkable structure for resolving tensions, the Constitution of the United States. It is difficult enough to coordinate the wills of 220 million Americans in regard to even one of the many emotion-stirring issues of penal law, such as capital punishment, gun control, abortion, obscenity, probation, parole, organized crime, traffic in narcotic and other drugs, espionage, riot control, wire-tapping or bail. To bring Congress to agreement simultaneously on a myriad of changes, each of which will be regarded by some as progress and by others as catastrophe, would appear to require a political miracle. Why should such a Herculean task be undertaken? What is the main direction of reform? What are the toughest issues to resolve, the chief obstacles to be overcome? What are the prospects?

This Article will describe the reform project in the setting of controversy: the clash between three versions of reform. The first was the Proposed Federal Criminal Code recommended in the Final Report of the National Commission on Reform of Federal Criminal Laws. That Commission will be referred to herein as the Brown Commission, after its Chairman, Governor Edmund G. Brown of California. Its proposed code will be referred to as the Commission Code.

A second version of the reform was embodied in bills numbered $S .1$ in the Ninety-third and Ninety-fourth Congresses. This version was sponsored chiefly by Senators McClellan of Arkansas and Hruska of Nebraska, conservative members of the Brown Commission and dominant members of the Subcommittee on Criminal Laws and Procedures of the Senate Committee on the Judiciary. The supporters of this bill will occasionally be referred to as "the Right." Following submission of the Brown Commission Report to Congress and the President, the Subcommittee held extensive hearings ${ }^{1}$ and published a three-volume proposed Report of the Judiciary Committee, of which Volume I is S. 1 of the Ninety-fourth Congress, the version of S. 1 usually referred to in this Article. That version of S. 1 was a blend of the original S. $1^{2}$ and S. $1400,{ }^{3}$ which was the Administration bill prepared by the Department of Justice. S. 1 closely resembled the Commission Code in form and in most of its substance, but it was overlaid by numerous "hard-

1. See Subcommittee Hearings.

2. S. 1, 93d Cong., 1st Sess. (1973), reprinted in Subcommittee Hearings, Part V, at 4211 (1973).

3. S. 1400 , 93d Cong., 1st Sess. (1973), reprinted in Subcommitree Hearings, Part V, at 4862 (1973); see id. at 4205 (remarks of Senator McClellan). 
line" changes that evoked powerful opposition. The latest bill, that of January 15,1975 , is the version reported by the Subcommittee to the full Committee on the Judiciary, and has itself been modified by nunerous subsequent proposed and agreed changes. Since it was clearly a draft in transition, it seems advantageous to focus on the earlier version, highlighting the issues it posed starkly.

I summarized my reaction to $S .1$ as follows in a memorandum on "Shortcomings of the McClellan Bill, S. 1":

It can be said generally of the contrasts between $S .1$ and the Brown Commission proposals that $S$. 1 expresses the view that the crime problem can and should be solved by extending government's power over individuals. This extension can take the form of wiretapping and other secret surveillance, of giving broad discretion to officials in decisions about punishment, of authorizing exceptionally severe sentences, or of restricting access to critical information about government operations. The other school of thought, represented by the Brown Commission, is skeptical about the gains in law enforcement that can be expected from such measures, and more concerned about impairing the quality of civil life by needless restraints on liberty. ${ }^{4}$

Contrary to the position of "the Left" described below, however, I believed that S. 1 contained much that was valuable, derived from the Brown Commission, and that the repugnant provisions of $S$. 1 could easily be excised by amendment.

The third version of penal reform was that of the National Committee Against Repressive Legislation (NCARL) and the American Civil Liberties Union, strongly supported by the National Lawyers Guild. I shall refer to this group as "the Left." The Left's version was only belatedly drafted in bill form ${ }^{5}$ because the Left's political position was that $S$. 1 was so pervasively reactionary that it could not be saved by amendment; yet their bills were inevitably and obviously revisions of S. 1 . No hearings were held or scheduled on these bills. Basically, the Left did not push an alternative reform; it concentrated on a campaign to stop S. 1.

\section{ORGANIZATION AND GOALS OF REFORM}

\section{A. Organization for Reform}

As I presently see it-for I came to this formulation near the end of my twenty-year involvement in penal reform rather than at the beginning-the main goal of penal reform is to promote respect for the law by making law respectable. This means that the reform must provide for fairer and more

4. Schwartz, Criminal Code: Shortcomings of the McClellan Bill, S. 1, 17 CRIM. L. REP. (BNA) 3203 (July 16, 1975), reprinted in SubCommItTEE HEARINGS, Part XII, at 384 (1975).

5. H.R. 10850, 94th Cong., 1st Sess. (1975); H.R. 12504, 94th Cong., 2d Sess. (1976). 
effective administration of justice in accordance with modern ideas. Obsolete offenses must be eliminated; inconsistent penalties must be reconciled; opportunities for arbitrary action must be narrowed; technical obstacles to conviction must be suppressed; severe penalties must be provided (and reserved) for offenses which today pose the greatest threats to society. In addition, the purview of the F.B.I. and the rest of the massive machinery of federal justice must be restricted to criminality of national significance, leaving responsibility for local law and order to the states and local communities.

A few concrete illustrations of the foregoing generalizations will clarify the meaning of "making the law respectable." Under current law, which provides no guidelines for sentencing and no appeal against arbitrary sentence, two men who have committed identical offenses may find themselves in adjoining federal prison cells serving outrageously different sentences, while a third like offender is granted probation and never goes to prison at all. Similarly, under current law a man who perpetrates a vast fraud, in the course of which he sends a letter through the United States mail, is liable to a maximum federal penalty of five years; ${ }^{6}$ another swindler whose loot is petty but who in the course of the scheme sends three letters is subject to a maximum of three times five years, or fifteen years. ${ }^{7}$ Current federal rape legislation does not differentiate between savage attacks by strangers and so-called "date-rape," that is, intercourse between voluntary companions which may indeed have been forced but only following tolerated sexual foreplay. ${ }^{8}$ Finally, trivial involvement of the telephone or other instrumentality of interstate commerce makes a "federal case" of innumerable petty local misdemeanors. Such grotesqueries undermine belief in the rationality of the system, and encourage the view that there is nothing immoral in trying to beat the system, whether the attempt is made by offenders or by defense lawyers.

The urge to make criminal law intellectually respectable by replacing the absurdities and anachronisms of prevailing law with rationality and consistency was expressed in the Model Penal Code of the American Law Institute. ${ }^{9}$ The Model Penal Code triggered a powerful movement for reform of the state criminal codes ${ }^{10}$ and was a progenitor of the federal reform. Many criticisms of current penal law had been documented in The Challenge of Crime in a Free Society, the landmark Report of the President's

6. See 18 U.S.C. $\S 1341$ (1970).

7. See note 74 infra.

8. See 18 U.S.C. $\$ 2031$ (1970).

9. See Model Penal Code (Proposed Official Draft, 1962).

10. See Subcommittee Hearings, Part II, at 558-59 (1971) (remarks of Professor Wechsler reporting on the status of state penal law revision); Wechsler, Codification of Crininal Law in the United States: The Model Penal Code, 68 Colum. L. Rev. 1425 (1968). 
Commission on Law Enforcement and the Administration of Justice. ${ }^{11} \mathrm{~A}$ National Commission on Reform of Federal Criminal Laws was established by Congress in $1966,{ }^{12}$ in response to pressure on the Johnson administration to "do something" about the "crime wave." The statute directed the Commission to carry out:

a full and complete review and study of the statutory and case law of the United States which constitutes the federal system of criminal justice for the purpose of formulating and recommending to the Congress legislation which would improve the federal system of criminal justice. It shall be the further duty of the Commission to make recommendations for revision and recodification of the criminal laws of the United States, including repeal of unnecessary or undesirable statutes and such changes in the penalty structure as the Commission may feel will better serve the ends of justice. ${ }^{13}$

The bipartisan Commission was composed of three members of the Senate Judiciary Committee (Senators McClellan, Hruska and Ervin), three members of the House Judiciary Committee (Representatives Kastenmeier of Wisconsin, Poff of Virgima and Edwards of California, later replaced by Mikva of Illinois), three federal judges (Judges Edwards of the Sixth Circuit, Higginbotham of the Eastern District of PennsyIvamia and MacBride of the Eastern District of California) and three Presidential appointees (former Governor Brown and attorneys Donald Scott Thomas of Austin, Texas and Theodore Voorhees of Washington, D.C.). ${ }^{14}$

There was a fifteen-member Advisory Committee, headed by former Attorney General and Supreme Court Justice Tom C. Clark. Among the Advisors were prosecutors, defense lawyers, police officials and experts in penology and constitutional law. ${ }^{15}$ Elliot L. Richardson, who had been U.S. Attorney im Boston and Attorney General of Massachusetts before going on to Cabinet and ambassadorial posts, was a member and spoke eloquently for reform. ${ }^{16}$ Leading members of the staff were likewise experienced pro-

11. President's Commission on Law Enforcement AND the Administration of Justice, The Challenge of Crime in a Free Society (1967).

12. Pub. L. No. 89-801, 80 Stat. 1516 (1966).

13. Id. $\S 3$.

14. For biographical summaries and identification of other members who served for a time, see Commission Final RePORT, Appendix B, at 361.

15. See Commission Final RePort, Appendix C, at 363.

16. In a speech to an Orientation Conference of U.S. Attorneys in Washington, on August 1,1969 , he related the mounting problem of criminal law enforcement to a general erosion of authority, whether of parents or governments, and to over-extension of penal prohibitions into areas of private morals. He concluded:

The ultimate test must lie in the law's capacity to enlist rational understanding and voluntary compliance. It is through applying this test that a body such as the National Commission on Reform of Federal Criminal Laws, for which I had the privilege of serving on the Advisory Committee, renders its most important service.... 
secutors and defense lawyers. ${ }^{17}$ Staff work was supplemented by special reports from expert consultants of every shade of opinion on particularly difficult issues. ${ }^{18}$

Perhaps the most important preliminary decision of the Brown Commission was to recognize a disparity between the breadth of the statutory mandate and the three-year deadline which Congress set for the Commission. Interpreting the broad scope of the mandate as defiming a range within which the Commission could select the most useful projects, I proposed, as Director of the Commission, that we draft a new federal substantive code. This meant that we would lay aside the divisive procedural issues, such as wire-tapping, over which Congress had fiercely and recently debated. ${ }^{19}$ It was evident that if we undertook to recanvass these issues we would spend three years continuing a recent acrimonious debate, and in the end say nothing new or authoritative.

The three-year deadline imposed a healthy urgency upon the Commission's work: we would do the best we could in the available time, abjuring the extensions that such projects are typically afforded. ${ }^{20}$ There are no natural limits to an enterprise of this sort, and perfection is an illusory goal. The Germans, for example, spent about a century attempting to perfect their proposed penal code. ${ }^{21}$ The American Law Institute deliberated for almost two decades on the Model Penal Code without even reaching such difficult matters as drug control, gambling, organized crime, political offenses and regulatory offenses. Commentaries to the Model Penal Code have not yet been published, mainly because it has proved impossible to keep up with the immense flux of penal developments in Congress and the fifty states, developments which seemingly should be related to the Code text. The efforts that had gone into the Model Penal Code saved us years of original work. We treated the Model Penal Code as a presumptively acceptable

. . . Having recognized that rationality and the skepticism which it has generated have contributed to the erosion of our system of order, we find in the end that our only sensible course is to invoke a deeper skepticism and a more constructive rationality. For it will take skepticism to identify those parts of the system that no longer make sense in a modern society, and it will take rationality to strengthen those elements of the system that are necessary to decent order among us.

STUDY DRAFT IXIV.

17. The Director had been a section chief in the Criminal Division of the U.S. Department of Justice. Deputy Director Richard A. Green had extensive experience as Assistant U.S. Attorney in the Southern District of New York, and thereafter as a defense attorney.

18. See 1, 2 Commission Working PAPERs.

19. See Omnibus Crime Control and Safe Streets Act of 1968, 18 U.S.C. $\$ \S 2510-2520$ (1970); Organized Crime Control Act of 1970, 18 U.S.C. $\$ 3504$ (1970).

20. A one-year extension plus a sixty-day wind-up period was granted, Pub.L. No. 91-39, 83 Stat. 44 (1969), allowing us time to take account of public response to the Study Draft which, due to printing delays, was not widely circulated until June, 1970. The extension also compensated for the six months required to organize the Commission and its staff.

21. See A. SchönKe \& H. SchrödER, StRAFgesetzbuch-Kommentar 1-5 (8th cd. 1976). 
tentative draft for a federal penal code, and drew heavily from the comments in the tentative drafts. ${ }^{22}$

Different groups have disparate goals, which in a democracy must be compromised and periodically rebalanced. As the community's economic, social and ethical character evolves, the "perfect" code, promulgated after ten or twenty-five years of deliberation, will already be obsolescent. ${ }^{23}$ The need, then, is to inject into the political and legislative consciousness the maximum feasible dose of accumulated knowledge and skill, rather than to engage in interminable philosophical and sociological inquiries.

An additional benefit of a relatively short deadline is that it tends to give the draftsmen a useful lead over the political forces which will eventually be marshalled against innovation. The California reform experience is enlightening in this connection. Before a draft could be completed, the project was aborted by politicians fearful of the possible electoral consequences of proposals to decriminalize private adult sexual behavior and use of marijuana. ${ }^{24} \mathrm{~A}$ protracted reform process makes each issue stand out as crucial, deprives particular proposals of the logical support provided by the entire context of the code, and magnifies the effectiveness of single-issue opposition groups, who are happy to hold a comprehensive reform hostage to satisfaction of their narrow concerns.

The three-year deadline also meant that we would not spend our time and the government's money trying to identify "the cause of crime." This decision seems so obviously correct as to be hardly worth mention, except for a criticism voiced in one quarter that the Commission should have begun its work with the sociological investigation. ${ }^{25}$ Criminal law reform has, and

22. An excellent review of state experience in drafting reform codes appears in SubCOMmittee Hearings, Part II (1971).

23. Consider, for example, the rapid evolution of views regarding the application of criminal law to private sexual relations and abortion. In 1959, the American Law Institute made the moderately liberal proposal to legalize abortions where a physician, with the concurrence of another doctor, believes "there is a substantial risk that continuance of the pregnancy would gravely impair the physical or mental health of the mother or that the child would be born with grave physical or mental defect. . . ." MODEL PENAL CODE § 207.11 (Tent. Draft No. 9, 1959). Although this proposal evoked conservative outrage at the time, it later proved to be unconstitutionally restrictive. See Roe v. Wade, 410 U.S. 113 (1973) (establishing woman's right to abortion for any reason during first trimester of pregnancy).

24. See Sherry, Criminal Law Revision in California, 4 U. MICH. J.L. REFORM 429 (1971), reprinted in SuBCOMMITTEE HEARINGS, Part II, at 623 (1971); Skolnick, Impediments to Criminal Law Reform: California, 1963-70, in SUBCOMmITTEe HEARINGS, Part II, at 654 (1971); Letter of Professor Herbert T. Packer, 22 STAN. L. REv. 160 (1969); For the Record, 17 U.C.L.A.L. Rev. vii (1969) (unbound volume only).

25. The Report of the Special Committee on the Proposed New Federal Criminal Law of the Association of the Bar of the City of New York on the Brown Commission Code began with a criticism that "without an investigation of the agonizing root causes of crime, an effective penal code cannot be constructed." Subcommitten Hearings, Part III, subpt. D., at 3478 (1972). See N.Y. Times, July 5, 1972, at 27, col. 5. Despite this introduction to its Report, the 
I dare say ever will have, a full agenda if it addresses itself to manifest abuses, inequalities, cruelties and anachronisms. Centuries of investigation into the etiology of crime have produced a marvelous array of explanations, including genetic defect, family disorganization, psychosexual compulsions, capitalist oppression, peer group pressures, the criminogenic tendencies of the penal system itself and, no doubt among fringe groups, sunspots and diet. The lawyer-legislator cannot wait for the conclusion of this endless effort of humanity to psychoanalyze itself. The practical question facing those responsible for legislation and government is what can we do meanwhile, before we know definitely either what causes crime in general or the particular cause for each of the infimite variety of crimes.

Early on, we decided to publish a preliminary study draft. ${ }^{26}$ The reasons were legal, political and strategic. The legal and political aspects can be passed over quickly. Our enabling legislation called for "interim reports to the President and the Congress at such times as the Commission may deem appropriate, and in any event within two years . . . ."27 The Study Draft was our compliance. ${ }^{28}$ For political reasons-and I do not use the phrase pejoratively-the Commission had to afford opportunity for pre-publication comment on our code by legislators, judges, prosecutors, the organized bar, government agencies and lobbyists of all sorts. The Study Draft provided that formal opportumity. This publication can be characterized more as political necessity than information-gathering because the Commission expected and received little new information after publication of the Study Draft; earlier informal staff contacts and the experience of Commission members, staff and the Advisory Committee had covered the ground.

Association's position was quite favorable to the Commission's proposals, while offering a number of carefully considered criticisms of particular provisions.

26. STUDY DRAFT. For a statement of the aims and main features of the draft, see id. at xxv. The draft was introduced to the legal community by a series of articles. See Brown \& Schwartz, New Federal Criminal Code is Submitted, 56 A.B.A.J. 844 (1970), reprinted in Subcommitree Hearings, Part I, at 50 (1971); Brown \& Schwartz, Sentencing Under the Draft Federal Code, 56 A.B.A.J. 935 (1970), reprinted in Subcommitree Hearings, Part I, at 56 (1971); Brown \& Schwartz, Offenses Redefined Under Proposed Federal Criminal Code, 56 A.B.A.J. 1181 (1970), reprinted in Subcommittee HeAringS, Part I, at 78 (1971); McClellan, Codification, Reform and Revision: The Challenge of a Modern Federal Criminal Code, 1971 DUKE L.J. 663.

27. Pub L. No. 89-801, \& 8, 80 Stat. 1516 (1966).

28. The Commission filed one other substantive interim report on March 17, 1969, recommending a standard immunity provision to replace the scores of divergent immunity provisions in existing law. The recommendation favored "use immunity" rather than "transactional immunity." The proposal was enacted in Title II of the Organized Crime Control Act of 1970, 18 U.S.C. $\$ \S 6001-6005$ (1970). Although this looks like an excursion beyond the Commission's chosen field of substantive reform to a controversial procedural issue, the fact that "transactional immunity" is a defense rather than a rule of evidence brought the issue plausibly within the Commission's self-imposed subject-matter limitation. The position taken clearly constituted a bid by the Commission for the confidence of the "law-and-order" elements among its own members and in Congress. 
The strategic importance of publishing an interim draft was considerable. In the first place, it compelled us to produce a complete draft well in advance of our deadline. That seemed the best way to avoid bogging down on those issues with which we happened to start our work. The experience of the drafters of the Model Penal Code had shown that in a large project time tends to be allocated not according to the importance of particular topics but according to the order in which topics are taken up. The first topics, however ummportant, swallow up massive fractions of time and energy simply because the participants have the impression that a great deal of time remains. Toward the end of the project, enormously difficult and important issues get summary disposition in the face of tomorrow's printing deadline. Having a complete draft long before that deadline provides an interval during which attention can be given to reworking the most crucial provisions.

A second reason for early formulation of a complete draft is that solid decisions cannot be made while drafting one provision of a code without knowing how other provisions are going to be handled. What is the general scheme of prison terms within which theft penalties are to be fitted? Is there to be a general section on "solicitation," or must each substantive section deal independently with solicitation to commit the specific offense? If the section dealing with attempt provides for penalties at a lower level than for completed offenses, shall this policy be rejected or qualified in particular applications, such as theft or burglary, where the definition of the crime embraces much behavior that, analytically, amounts to attempt?

Another strategic consideration in favor of preparing a complete tentative draft is that the staff enjoys more freedom and can proceed more rapidly than would be possible if the Commission had to be fully persuaded at every stage of progress. The Commission was composed of very busy people. Meetings could not be scheduled more frequently than once in two months, and some members could not attend regularly or throughout the day or days of a scheduled meeting. There was a natural tendency to defer serious consideration until the last moment when final decisions had to be made. $A$ study draft in which no decision purports to be final is well adapted to such a situation. Commission members could take a more relaxed attitude toward proposals they might later come to view with alarm. Not only would the staff be allowed more leeway in a study draft, but a draft in being would enjoy a certain tactical advantage in subsequent Commission debates.

Not surprisingly, the Study Draft was somewhat more radical than the Final Draft. The members of the Commission who were well aware of the strategy of the situation (a) reviewed the Study Draft provisions scrupulously; (b) changed its proposed title from "Tentative Draft" (which was functionally accurate) to the more noncommittal "Study Draft"; (c) overrode the Director on some points and required inclusion in the Study Draft of 
alternative positions espoused by minority members; ${ }^{29}$ and (d) insisted on a declaration in boldfaced type on the cover that "The Study Draft provisions are not to be taken as representing the position of the Commission on any particular issue." Significantly, as the printing deadline for the Final Report approached, some members of the Commission, notably Senators McClellan and Hruska, became increasingly reluctant to be bound even by the Commission's tentative decisions. At the same time, however, they desired to strengthen the impetus toward revision of the federal penal code by having the Commission submit a "unanimous" report. The result was "unanimous" support of the Final Draft "as a work basis upon which the Congress may undertake the necessary reform . . . . Individually we have reservations, sometimes strong, on the resolution of particular issues." 30 Like the Study Draft, the Final Report articulated alternatives favored by minority members (usually conservative). Not surprisingly, these minority positions came to supersede the Commission's majority views when the Senate Subcommittee revised the Commission's Code for incorporation in S. 1.

The Commission's Final Report was delivered on February 10, 1971, in a formal ceremony in the Hearing Room of the Senate Judiciary Committee amid a chorus of approbation and mutual congratulations. ${ }^{31}$ Attorney General John Mitchell accepted it for President Nixon, going so far as to dismiss as "nonsense" a criticism already heard in some quarters that the jurisdictional provisions of the Commission's Code were too comprehensive, overrode states' rights, and portended the creation of a vast 'federal police." 32 The Attorney General's epithet was entirely appropriate, but it

29. See, e.g., STUDY DRAFT, ch. 36 (capital punishment); id. $\$ \S 1005,3203$ (special sentencing for organized crime); id. $\$ 3204$ (sentences up to one year for misdemeanors, where the Director favored from one to three months); id. $\S 405(1)$ (b) (proposal for class actions to reimburse victims of corporate crime, deleted in final code). For a full list of changes between the Study Draft and the Final Report, see Commission FINAL RePORT 343.

30. Letter from Edmund G. Brown to the President and Congress (Jan. 7, 1971), reprinted in COMMISSION FinAL REPORT i.

31. See Subcommittee Hearings, Part I, at 1-128 (1971).

32. See Liebmann, Chartering a National Police Force, 56 A.B.A.J. 1070, 1071 (1970), reprinted in SubcommitTeE Hearings, Part I, at 64, 65 (1971):

From these modest beginnings there has sprung forth a monster. The proposed study draft works not a revision and rearrangement of the federal criminal code... but rather a wholesale expansion of federal police power and a wholesale destruction of state responsibility and state autonomy in the preservation of public order and the administration of criminal law.

See also Resolution of the National Association of Attorneys General, in SUBCoMmitTEE HEarings, Part I, at 6, 9 (1971). These critics were primarily concerned by $\& 201(\mathrm{~b})$ of the Commission Code, the so-called "piggyback" provision-which allows federal prosecution of all crimes involved in a single episode if federal jurisdiction exists for any of the crimes. The response to this criticism is twofold: First, the section is simply one element in a catalogue of available jurisdictional bases and is inoperative except as explicitly adopted in a substantive section of the code; second, the provision does not expand current federal jurisdiction. Existing federal law follows the "piggyback" principle quite haphazardly, as in 
was prudently excised from the stenographic transcript of the proceedings. That was the first small retreat from the Brown Commission.

Under President Nixon's instructions, the Department of Justice began the study and revision of the Commission Code ${ }^{33}$ which would lead to the administration bill, S. 1400, in the Ninety-third Congress. Senator McClellan, Chairman of the Subcommittee on Criminal Laws and Procedures of the Senate Judiciary Committee, instituted the monumental consideration of the Commission Code that eventuated in S. 1. The priority which Senator McClellan was prepared to assign to revision of the penal code is suggested by the bill number which he secured for it; it may be recalled that $S .2$ in the Ninety-third Congress dealt with no trivial matter-liquidation of the Vietnam War. ${ }^{34}$ The clever, scholarly and indefatigable Professor G. Robert Blakey, who had been in effect counsel to the conservatives on the Brown Commission, was put in charge of the staff of the Subcommittee project.

The Subcommittee on Criminal Justice of the House Judiciary Committee, although dominated by liberals, including Representatives Kastenmeier and Edwards who had served on the Brown Commission, was not prepared to move so fast. The Commission Code was duly embodied in a bill, H.R. 330 , but no hearings were scheduled. The reasons for this were mixed and obscure. Some had to do with conflicts of priorities in the House Judiciary Committee. ${ }^{35}$ There was also a feeling in some quarters that the conservative thrust of the Senate could be most effectively countered by waiting out the battle there between conservatives and liberals, after which the Senate's version could be bottled up or cut up in the House. Some felt that postpoming action until a Democratic President and a new Congress convened in 1977 would assure a better product as well as credit to the Democrats. House liberals were content for the moment, therefore, to go along with the movement to defeat $\mathrm{S} .1$ by sponsoring the belated and hastily drafted alternative bills H.R. 10850 and H.R. $12504 .^{36}$ The pressure of these bills

provisions for life imprisonment where "death results" in connection with malicious mischief to interstate vehicles, 18 U.S.C. $\$ 34$ (1970), or civil rights offenses, id. $\$ 245(b)(5)$, and provisions for the imposition of the death penalty where a killing occurs in connection with a bank robbery, id. $\$ 2113(\mathrm{e})$.

33. Representatives of the Department had, of course, followed the Commission's deliberations closely, attending meetings as observers and commenting informally on staff drafts. Ronald F. Gainer, Director of the Justice Department's Office of Policy and Planning and an able, experienced and perceptive public servant, was the Department's principal liaison officer with the Commission and was subsequently put in charge of the Department's work on the penal reform legislation.

34. S. 2, 93d Cong., 1st Sess. (1971) (a bill "to Provide for the Cessation of Bombing in Indochina and for the Withdrawal of U.S. Military Personnel from the Republic of Viet Nam, Cambodia and Laos').

35. Among other extensive and controversial projects occupying the Committee during the relevant period were revision of the copyright law, review of the proposed Federal Rules of Evidence, and impeachment of President Nixon.

36. See notes $245-63$ infra and accompanying text. 
helped to discourage a crucial and surprisingly liberal compromise that seemed about to emerge in the Senate in the spring of 1976.

\section{B. Basic Policy: Deterrence; Role of Retribution}

The Commission embarked on the reform project with the generally shared hypothesis that, whatever the ultimate causes of crime may be, a counter-incentive should be provided by a system of threats of punishment. Deterrence or, more broadly, prevention, is thus the basic policy that underlies the Code, although the Code's statement of purposes, which is intended to guide interpretation and administration of the statute, includes not only rehabilitation but also retribution. ${ }^{37}$

The draftsmen did not, of course, entertain the naive notion that all crimes are deterrable. There are crimes of passion and patriotism that seem virtually undeterrable. There are also people who commit offenses precisely because of a desire to suffer consequences or to savor extreme risks. Perhaps we should not even regard such desires as pathological, in that "sane" men climb Mt. Everest, but merely register the observation that the number of risk-seeking offenders is so small as not to count in any formulation of general penal policy. It is worth remembering that even in insane asylums (read "hospitals" if so inclined) dealing with minimally deterrable people, rules and sanctions are used to promote essential decency and order.

It is widely believed that most human activity-indeed, most animal activity-is governed by a pleasure-pain calculus. On that hypothesis society bases not only its deterrent penal codes, but also its entire system of affirmative awards: profits for entrepreneurs, salary increases for bureaucrats, Nobel Prizes for scientists and artists, patents for inventors, tax incentives for investment in petroleum exploration, prizes and scholarships for academic achievers, and so on. To believe that these contingent rewards do not influence attitudes and behavior is to reject the deterrent hypothesis in criminal law. ${ }^{38}$

In the Commission Code, if not in S. 1, retribution serves its classic and least objectionable function of setting limits on the state's power to punish. It is this notion that underlies, for example, the declared policies in favor of requiring proof of "culpability",39 and in favor of the defense of

37. "[T] $]$ he provisions of this Code are intended . . . to achieve the following objectives: (a) to insure the public safety through (i) vindication of public norms by the imposition of merited punishment; (ii) the deterrent influence of the penalties ... provided; (iii) the rehabilitation of those convicted ...." COMMISsION CODE $\S 102$. S, 1 recited approximately the same range of goals, but manifested a priority for retribution by prescribing "sanctions . . . that will assure just punishment." S. 1 101(b) (emphasis added). See also the critical departures of S. 1 from the Commission Code in regard to standards for probation and parole, discussed at text accompanying notes 177-85 \& 191-93 infra.

38. See J. Andenaes, Punishment and Deterrence (1974); F. Zimring \& J. Hawkins, Deterrence: The Legal Threat in Crime Control (1973).

39. The Commission Code provides that guilt without culpability shall exist only where 
insanity. ${ }^{40}$ It is often forgotten that the saying "an eye for an eye; a tooth for a tooth" was in its time a policy of moderation, for the alternative was likely to be capital punishment for mere wounding or theft. Equally true in our day, when many people insist on extreme penalties as essential to security or mandated by Holy Writ, the common man's sense of "proportionality" (i.e. retribution) serves to mimmize the scope of application of those penalties, for example, by excluding capital punishment for attempted murder ${ }^{41}$ and for non-homicidal offenses. ${ }^{42}$

In any event, retribution as a goal of the criminal law could not, as a practical matter, be excluded from a democratically enacted code in this country, where massive popular support for retribution has recently been demonstrated by the surge of capital punishment legislation following the Supreme Court's invalidation of older arbitrary procedures for imposing it. ${ }^{43}$ Justice Stewart's opinion in Gregg v. Georgia, ${ }^{44}$ sustaining Georgia's revised capital punishment procedures, restores to retribution a legitimacy which it had begun to lose, at least in some professional circles:

In part, capital punishment is an expression of society's moral outrage at particularly offensive conduct. This function may be unappealing to many, but it is essential in an ordered society that asks its citizens to rely on legal processes rather than self-help to vindicate their wrongs. "The instinct for retribution is part of the nature of man, and channeling that instinct in the administration of criminal justice serves an important purpose in promoting the stability of a society governed by law. When people begin to believe that organized society is unwilling or unable to impose upon criminal offenders the punishment they 'deserve,' then are sown the seeds of anarchy-of self-help, vigilante justice, and lynch law. ...." "Retribution is no longer the dominant objective of the criminal law," . . . but neither is it a forbidden objective nor one inconsistent with our respect for the dignity of

the statute expressly so permits, COMMISsion CODE $\$ 302(2)$, and that criminal negligence, as distinguished from civil negligence, requires proof of a "gross deviation from acceptable standards of conduct." Id. $\S 302(1)(d)$. S. 1 substitutes the non-committal phrase "state of mind" for "culpability," S. $1 \S 301$, and does not insist on an explicit statutory basis for strict liability for the numerous regulatory offenses outside the criminal code. Id. $\S$ 303(a)(1)(B).

40. Commission Code $\S 503$. S. 1 permits only limited use of the insanity defense. S. $1 \S$ 522. See Part IV. B. infra.

41. For a sophisticated analysis that would, on deterrent grounds, equate the penalties for murder and attempted murder, see Schulhofer, Harm and Punishment: $A$ Critique of Emphasis on the Results of Conduct in the Criminal Law, 122 U. PA. L. REv. 1497 (1974).

42. Most states do not penalize rape or armed robbery by capital punishment, and it has now been questioned whether statutes that do provide such penalties are invalid under the eighth and fourteenth amendments. See Gregg v. Georgia, 428 U.S. 153, 187 n.35 (1976) (reserving judgment as to whether capital punishment is unconstitutionally "disproportionate" to such offenses).

43. Furman v. Georgia, 408 U.S. 238 (1972). The ensuing legislative response is summarized in Gregg v. Georgia, 428 U.S. 153, 178-83 (1976).

44. 428 U.S. 153 (1976). 
men. . . . Indeed, the decision that capital punishment may be the appropriate sanction in extreme cases is an expression of the community's belief that certain crimes are themselves so grievous an affront to humanity that the only adequate response may be the penalty of death. ${ }^{45}$

In vain did Justice Marshall, dissenting with Justice Brennan, point out that life imprisonment might well be regarded, in the United States as in most advanced Western civilizations, as adequate "expression of [society's] moral outrage." "46 The frighteming implications of the proposition that society may be as cruel to the despised criminal as he "deserves" are only partially mitigated by Justice Stewart's concurrent declaration that punishment must not be "excessive" or inconsistent with "the dignity of man," the "basic concept underlying the Eighth Amendment." 47 We shall see that a fundamental cleavage between S. 1 and the Commission Code concerns the emphasis to be given to retribution.

Rehabilitation is a declared goal of S. 1 , as well as the Commission Code, notwithstanding growing skepticism as to the feasibility of reconstructing character in a penal setting. ${ }^{48}$ At the least, efforts should be made, during a period of incarceration mandated for other purposes, to educate, motivate and resocialize the offender. The goal of rehabilitation also mandates concern that the circumstances of detention and the length of imprisonment not be destructive of the personality of prisoners.

\section{SOME COMmon GROUND: CONSENSUS REFORMS}

My detailed criticisms of S. 1 and S. 1400 have been published elsewhere. ${ }^{49}$ What may usefully be done here, before going on to identify crucial issues that remain to be resolved, is to outline the progressive elements which S. 1 adopted from the Commission Code, or even added to it, and with respect to which a substantial consensus already exists.

\section{A. Basic Structure of the Code; Federal Jurisdiction}

All agree that the United States, which has never before had a comprehensive, logically organized and internally consistent penal code, shall

45. Id. at 183-84 (quoting Furman v. Georgia, 408 U.S. 238, 308 (1972); Williams v. New York, 337 U.S. 241, 248 (1949)) (footnotes omitted).

46. 428 U.S. at 283 (Marshall, J., dissenting).

47. Id. at 173 (quoting Trop v. Dulles, 356 U.S. 86,100 (1958)).

48. See M. Frankel, CRIMINAL SENTENCES: LAW Without ORDER 86-102 (1973); Allen, Criminal Justice, Legal Values and the Rehabilitative Ideal, 50 J. CRIM. L.C. \& P.S. 226 (1959).

49. See Schwartz, supra note 4; Schwartz, The Proposed Federal Criminal Code, The Administration's Bill, S. 1400, 13 CRIM. L. REP. (BNA) 3265 (1973), reprinted in SUBCOMMITTEE Hearings, Part X, at 6980 (1974). See also Schwartz, The Proposed Federal Criminal Code, Comparison of S. 1 and the Recommendations of the National Commission on Reform of Federal Criminal Laws, in Subcommittee Hearings, Part V, at 5380 (1973). 
now have one. In place of the present Title 18 of the United States Code, which is merely an assembly of ancient and new provisions arranged alphabetically with little regard to the content of successive chapters, the new code will have three main divisions. These will deal, respectively, with general matters, ${ }^{50}$ specific offenses ${ }^{51}$ and the sentencing system. ${ }^{52}$ The General Part will cover federal jurisdiction (that is, the scope of application of the federal code) ${ }^{53}$ definitions (never before undertaken by Congress) of "intention,"54 "recklessness,",55 "negligence,"56 exculpating "mistake,"57 "insanity"58 and other elements of mens rea;" the liability of accomplices $^{60}$ and corporations; $; 1$ the statute of limitations; $; 2$ and other similar matters.

The very important problems of justification and excuse would also be dealt with in the General Part. ${ }^{63}$ These defenses to prosecution have heretofore been totally disregarded by Congress, so that the courts have had to develop the law on a case-by-case basis, predictably producing inconsistencies and ambiguities. ${ }^{64}$ Since the operational effect of a penal provision results from a combination of prohibition and exceptions or defenses, it is strange and potentially unconstitutional on grounds of vagueness to have criminal laws say, in effect, "Thou shalt not do $X$. . . except as the courts qualify this prohibition by recognizing justifications and excuses." On the other hand, the issues of justification and excuse are perplexing, and penal theory in this area is primitive. We shall see below that, while there is agreement that the Code should address itself to defining the defenses, very sharp controversy remaims as to how far to go along that road. ${ }^{65}$

The problems of federal penal jurisdiction may be analyzed under four main headings: (1) the core of the federal government's power to preserve itself and carry out federal functions (herein of treason, espionage, tax and

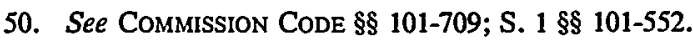

51. See Commission CoDE $\S \S 1001-1861 ;$ S. 1 §§ 1001-1863; Brown and Schwartz, Offenses Redefined Under Proposed Federal Criminal Code, supra note 26, at 78.

52. See COMMISSION CODE $\$ \$ 3001-3604 ;$ S. 1 \$ 2001-2403.

53. See Commission Code $\$ \S 201-219 ;$ S. 1 \$ 201-205.

54. CoMmission CODE $\$ 302(1)(a) ; S .1$ \$ 302(a).

55. COMMISSION CODE $\S 302(1)(c) ;$ S. 1 \$302(c).

56. COMMISSION CODE $\$ 302(1)(\mathrm{d}) ; \mathrm{S} .1$ \$ 302(d).

57. COMMISSION CODE § 609; S. 1 § 521 .

58. COMMISSION CODE $\S 503 ; \mathrm{S}$. $1 \S 522$.

59. See generally COMMISSION CODE $\S \S 301-305 ;$ S. 1 \$ 301-303.

60. Commission CODE $\S 401 ;$ S. $1 \S 401$.

61. COMMISSION CODE $\S \S 402-403 ;$ S. 1 § 402.

62. COMMISSION CODE $\S 701 ;$ S. 1 \& 511 .

63. COMmISSION CODE $\S \S 601-610,619 ;$ S. 1 § 521-523, 531, 541-544, 551-552.

64. One such example is the insanity defense. At present, at least five different formulas are being utilized in the federal courts. See 1 CoMmission WORKING PAPERS 229-47. 65. See notes 150-54, 212-14, 230-46 infra and accompanying text. 
customs violations, etc.); (2) the territorial scope within which federal legislative power is plenary (federal enclaves, American vessels on the high seas) and where the federal penal code would be, in principle, as comprehensive as that of an ordinary state; (3) the question of "assimilated crimes" - state-defined offenses which Congress adopts by reference for application in federal enclaves; ${ }^{66}$ and (4) the question of the extent to which Congress should, by using its constitutional power (for example, over interstate commerce or the mails), make federal crimes out of behavior that is already penalized by state law.

Only this last category of federal jurisdiction calls for discussion here. I have described and sought to rationalize this federal auxiliary criminal jurisdiction elsewhere. ${ }^{67}$ It came into existence in the nineteenth century to deal with multi-state crime, notably large-scale frauds. Initially, the thought was simply to deny the use of federal facilities, for example, the mails or facilities of interstate communications or commerce, to those who would employ them for nefarious purposes. ${ }^{68}$ "Use of the mails" to carry out the scheme was conceived of as the "gist" of the "mail fraud" offense, 69 and every separate use of the mails was a distinct offense for purposes of prosecution and punishment. ${ }^{70}$ The fraudulent operation itself remained theoretically the responsibility of the states. ${ }^{71}$

This theoretical nicety had unfortunate practical consequences which will be eliminated by common consent in the new federal penal code. First, the United States found it difficult to extradite fugitive swindlers because extradition treaties generally required that the behavior be penalized in both the demanding and the extraditing state, and foreign countries knew no such offense as "mail fraud." Second, since each posting was a separate offense,

66. See 18 U.S.C. $\S 13$ (1970); Commission Code $\S 209 ;$ S. 1 \& 1863. See also 1 COMMISSION WORKING PAPERS 33, 77-103. Any federal code must incorporate by reference masses of minor local traffic and other regulations, on which Congress should not waste its time and which in any event ought ordinarily to conform with the regulations of neighboring non-enclave communities.

67. Schwartz, Federal Criminal Jurisdiction and Prosecutors' Discretion, 13 LAW \& CONTEMP. PROB. 64 (1948).

68. See id. at 74-75.

69. See, e.g., Durland v. United States, 161 U.S. 306, 315 (1896): "It is enough if, having devised a scheme to defraud, the defendant with a view of executing it deposits in the post office letters, which he thinks may assist in carrying it into effect, although in the judgment of the jury they may be absolutely ineffective therefor." See also Schwartz, supra note 67, at 79: "Courts find themselves talking nonsense like the oft-repeated declaration that the use of the mails is the 'gist' of the offense of mail fraud, when all that is meant is that this federal jurisdictional element must, of course, be alleged and proved" (footnote omitted).

70. See note 74 infra.

71. See Parr v. United States, 363 U.S. $370,389-90$ (1960) (a scheme to defraud by misappropriating school district's moneys and property constitutes essentially a state crime and can be federal only if mails are used for the purpose of executing such a scheme). 
federal prosecutors could secure multiple indictments for a single fraud. ${ }^{72}$ The situation was aggravated as the mail fraud statute was amended to permit prosecution not only for posting but also for causing nefarious mail to be delivered.$^{73}$ Since substantial frauds might involve thousands of mailings, the number of offenses charged and therefore the limits of punishment became virtually a matter of prosecutorial discretion. Third, when there was a conviction on several counts, some federal judges carried the logic of "mailings-as-the-gist-of-the-offense" to its ridiculous conclusion: not satisfied with the statutory maximum of five years which Congress had prescribed for mail fraud, they would impose consecutive five-year sentences for separate mailings. ${ }^{74}$ The situation was aggravated by the enactment at different times of federal statutes using different constitutional bases to penalize fraud, extortion, or dissemination of obscenity. ${ }^{75}$ Thus, different federal offenses, sometimes differently penalized, might be committed depending on whether the accused employed the mail or the interstate telephone, or on whether the contraband was imported from abroad or transported in interstate commerce. Moreover, under the doctrine that state and federal governments might both prosecute and punish identical misbehavior offending their separate "sovereignties," the accused were exposed to official abuse of power that violated the spirit if not the letter of the constitutional prohibition against double jeopardy. ${ }^{76}$ Finally, the inevitable differences between the federal definition of a particular category of offense and the cognate offense under state law produced anomalies. For example, unlike the false pretenses statutes of most states, the federal niail fraud law could be used to punish misrepresentations of opinion, value, intention or law. ${ }^{77}$ The result is that in a strictly local swindle, criminal liability may depend on whether prosecution is undertaken by federal authorities or local prosecutors.

As federal penal legislation has proliferated in the twentieth century, it has become evident that the role of the federal government can no longer be

72. Judicial revulsion against such scholastic excesses may be seen in Bell v. United States, 349 U.S. 81 (1955) (transport of several women in interstate commerce on a single occasion is a single offense). But cf. Gore v. United States, 357 U.S. 386 (1958) (multiple, different charges based on a single narcotics transaction).

73. 25 Stat. 873 (1889) (amending 70 Rev. Stat. $\$ 5480$ (1878)).

74. See, e.g., Becker v. United States, 91 F.2d 550 (9th Cir. 1937) (two five-year sentences to be served consecutively for two letters to the same victim); Beckett v. United States, 84 F.2d 731 (6th Cir. 1936) (cumulating sentences permitted but caution and moderation should rule its exercise); cf. Sanders v. United States, 415 F.2d 621 (5th Cir. 1969) (defendant could have received maximum consecutive sentences totaling 115 years under multiple count fraud indictment).

75. See, e.g., 18 U.S.C. $\$ \S 1001-1027$ (1970) (fraud and false statements); id. $\$ \S 872$, 875-877, 1951 (extortion); id. §§ 1461-1464 (obscenity).

76. See Abbate v. United States, 359 U.S. 187 (1959) (earlier state court conviction does not bar federal prosecution under the double jeopardy clause of the fifth amendment).

77. See United States v. Rowe, 56 F.2d 747 (2d Cir. 1932). 
regarded as merely protecting federal facilities from wrongdoers. In reality we have two largely overlapping systems of criminal justice. Occasionally, all pretense of a confined role for the federal government has been abandoned where plenary federal jurisdiction (not, however, preclusive of parallel state enforcement) ${ }^{78}$ is claimed by Congress on the basis of its findings that local, interstate and international operations are inextricably intertwined. ${ }^{79}$

The changed role of federal penal law is reflected in both the Commission Code and S. 1. The definitions of offenses are in terms of conduct and culpability just as in state and foreign national codes. The question of the circumstances under which the federal government may and should intervene is dealt with separately, ${ }^{80}$ making it impossible any longer to regard the

78. See, e.g., 18 U.S.C. $\$ 896$ (1970) (Organized Crime Control Act):

This chapter [extortionate credit transactions] does not preempt any field of law with respect to which State legislation would be permissible in the absence of this chapter. No law of any State which would be valid in the absence of this chapter may be held invalid or inapplicable by virtue of the existence of this chapter, and no officer, agency, or instrumentality of any State may be deprived by virtue of this chapter of any jurisdiction over any offense over which it would have jurisdiction in the absence of this chapter.

79. See, e.g., Comprehensive Drug Abuse Prevention and Control Act of 1970, 21 U.S.C. $\$ 801$ (1970). A similar plenary federal jurisdiction has been asserted in the drive against organized crime. See 18 U.S.C. $\$ \$ 891-894,896$ (1970) (loansharking); cf. Perez v. United States, 402 U.S. 14 (1971) (sustaining constitutionality of the loansharking jurisdiction). The Brown Commission accepted the recently enacted plenary jurisdiction approach to the loansharking offense. See Commission CODE $\$ 1771$, Comment, at 238 (timidly proferring the suggestion that such "jurisdiction may be overbroad").

A like treatment was proposed in S. 1 for the quite comprehensively defined "racketeering" crimes (\$\$ 1801-1804, 1806). In discussing the scope of these crimes, the Senate Judiciary Subcommittee Report stated:

This slightly expands current law, which requires that the enterprise be engaged in or affect interstate or foreign commerce. As a practical matter, virtually every enterprise's activities under this section would meet the "affect" criterion. However, the Committee believes that it should not be necessary to show a nexus with interstate commerce in view of the findings and purpose expressed by Congress in the Organized Crime Control Act of 1970 , to the effect that the activities of organized crime in the aggregate have a substantial adverse impact upon a variety of Federal interests, including but not limited to interstate and foreign commerce.

3 SUBCOMMITTEE REPORT 773. Similarly, S. 1 utilized the plenary jurisdiction approach for various drug offenses. See S. $1 \S 1811$ (trafficking in an opiate), 1812 (trafficking in drugs), 1813 (possessing drugs) and 1814 (violating a drug regulation).

80. In the Commission Code, the twelve "common jurisdictional bases" are catalogued in section 201. Thereafter, a simple cross-reference in each substantive offense section serves to designate the particular basis Congress wishes to invoke for that of fense. This greatly simplifies and shortens the substantive offense sections. The arrangement was, however, misconstrued by inattentive readers, who supposed that section 201 was a consolidation of all possible jurisdictional bases to be available for federal prosecution of any offense. Others may well have been shocked simply to discover the breadth of federal potential, and were disinclined to give a prominence to the phenomenon or to provide Congress with an easy format for enlarging the federal role if it so desired.

These anti-federalist fears were sought to be assuaged in S. 1 by dismantling the catalogue. This required spelling out in each substantive section the various federal bases applicable to that section. Although the operative effect is quite close to the Commission's jurisdictional 
jurisdictional base as the gist of an offense. S. 1 followed the Commission Code in declaring that "culpability is not required with respect to any fact which is solely a basis for federal jurisdiction." 81 That is, a defendant's guilt of a substantive federal offense does not require proof that he knew he was on federal territory or that he was "affecting" interstate commerce. Artificial multiplication of charges is eliminated by declaring that " $[t]$ he existence of multiple jurisdictional bases for an offense does not increase the number of offenses committed." 82

Despite a huge pseudo-controversy, another area of general substantive agreement was the so-called "piggyback jurisdiction." The issue relates to violations of federal laws, for example, civil rights, safety of interstate transportation, or robbery of national banks, where the core transgression against federal interests is accompanied by death or other personal aggression cognizable under state law. While such killings, kidnappings and similar offenses might have been left to separate prosecution by the state, the practical answer was to have every aspect of the controversy disposed of in a single federal prosecution. That answer is incorporated in present federal law, albeit awkwardly, by prescribing specially severe sentences for certain violations if a killing occurs. ${ }^{83}$ All pending proposals adopt this approach with insubstantial variations. ${ }^{84}$

arrangements, the drafting becomes unhappily turgid. See, e.g., S. 1 \& 1731(c) (thirty jurisdictional bases for theft).

Paradoxically, the one section of the Commission Code that would have strongly reaffirmed state responsibility for local offenses disappeared in S. 1. Commission Code section 207 called upon federal law enforcement agencies to abstain from exercising a technically available jurisdictional power where the offense had no substantial out-of-state or federal dimension. Rather than retaining this provision the Senate Judiciary Subcommittee adopted a different approach:

[S. 1] provides for submission by the Attorney General of annual reports to Congress, setting forth for each offense the number of prosecutions commenced during the preceding year, and identifying the number prosecuted under each particular circumstance giving rise to Federal jurisdiction. This is designed to provide the Congress with information that will flag any material increase or decrease in Federal prosecution in particular areas, thereby permitting inquiry to be made into the reasons for such increase or decrease and prompting periodic evaluation of the proper scope of Federal jurisdiction in such areas.

2 SUBCOMMITTEE REPORT 33. Growing familiarity of the legal profession with the true import of the Commission's jurisdictional arrangement may permit a return to the simpler formulation in subsequent bills and a revival of Commission Code section 207.

81. CoMmission CODE $\S \S 204,302(3)(c) ;$ S. $1 \S 303(d)(2)$.

82. COMMISSION CODE $\S 205$; cf. S. 1 \& 201(b)(1).

83. See note 32 supra.

84. The discussions concerning "piggyback" jurisdiction were briefly summarized in the Senate Judiciary Subcommittee Report:

[T] he concept has the advantages of permitting a unitary adjudication and punishment of a defendant's entire course of criminal behavior, when a series of offenses is committed in the course of a Federal crime. However, indiscriminate application of this jurisdictional notion could also drastically impinge upon the traditional prerogatives of the States by permitting Federal prosecution for offenses where there exists only a tenuous Federal nexus at best. 


\section{B. Modernized Definition of Offenses}

A second major front on which S. 1 marches forward in the track of the Commission 'Code, although with some stumbling, is bringing the definition and grading of offenses into accord with twentieth-century conditions and values. A notably new comprehensive "theft" section will replace the crazy patchwork of existing sections dealing with many versions of larceny, embezzlement, fraudulent conversion and obtaining by false pretenses. ${ }^{85}$ The opportunities for crooks to slip through the technical holes in the present net will be narrowed. Penalties will be graduated according to the scale of the thievery ${ }^{86}$ The same grading principle will govern the penalization of tax fraud. ${ }^{87}$ High corporate officials will be responsible for corporate crimes if they contribute to the offense by willful or reckless default in a duty to supervise corporate behavior.$^{88}$ Fine levels will be systematically graded, and, for offenses involving pecuniary gain, may go as high as twice the amount of the gain or twice the loss caused to the victim..$^{89}$ Making use of the sensitivity of major corporations to adverse public and political reactions, corporate misbehavior will be discouraged by requiring the organization to publicize convictions. ${ }^{90}$ Convicted corporate officers may be disqualified from exercising management functions similar to those they had abused. ${ }^{91}$ These advances in control of white-collat and high corporate crime are alone enough to expose the absurdity of charges from the Left that

2 SubCommittee Report 30. See also id. 29-32; Note, Piggyback Jurisdiction in the Proposed Federal Criminal Code, 81 YALE L.J. 1209 (1972).

85. See COMMISSION CODE $\S \S 1731-1735,1741$; S. 1 §§ 1731-1738. See also CoMmission FINAL REPORT 205 (introductory note on theft and related offenses); 3 SUBCOMMITTEE REPORT 649-703.

86. COMMISSION CODE $\S 1735 ;$ S. 1 \& 1731(b).

87. COMMISSION CODE § 1401(2); S. 1 § 1401(b).

88. COMMISSION CODE $\S 403(4) ;$ S. $1 \S 403($ c).

89. COMMISSION CODE § 3301; S. 1 § 2201.

90. COMMISSION CODE $\S 3007 ; \mathrm{S} .1 \S 2004$. Under these sections the corporation or organization that has been found guilty of an offense may be ordered by the court to give notice of the conviction to the class of persons or to the sector of the public affected by the conviction or financially interested in the subject matter of the offense by mail, by advertising in designated areas or through designated media or by other appropriate means. It is interesting to note that while conservative members of the Commission favored a narrower publicity sanction, compare COMmission CODE $\S 3007$ with STUDY DRAFT § 405(1)(a), S. 1 adopted the broader version. The use of unfavorable publicity as a sanction against corporate depredations is an idea whose time has come. See Federal Trade Commission Improvements Act of Jan. 4, 1975 (codified at 15 U.S.C.A. \& 57b(b) (Supp. 1976)) (public notification respecting rule violation or unfair or deceptive act or practice). See generally COMMISSION WORKING PAPERS 166, 191-93.

91. Commission CODE § 3502; S. 1 § 1-4A3(b), 93d Cong., 1st Sess. (1973) (McClellan draft), reprinted in SubCOMMITTEE HEARINGS, Part V, at 4248 (1973). In S. 1 \$ 2103(b)(6) and 3834(c), this disqualification of corporate officers appears in modified form as a permissible condition of probation or parole, respectively. 
S. 1 was a fascist conspiracy between the "Nixon men" and Senator McClellan to enslave the American people. ${ }^{92}$

Interestingly, S. 1 actually made some advances over the Brown Commission in the civil rights area, where the Commission was cautiously content to codify existing law. The civil rights offenses are broadened to protect aliens as well as citizens. ${ }^{93}$ Infringement of civil rights is made an offense when perpetrated by an individual, and not merely, as at present, when perpetrated by several persons in conspiracy. ${ }^{94}$ Provisions against sexual discrimination have been added to the civil rights sections. ${ }^{95}$ The offenses of rape and cognate aggressive homosexuality have been consolidated so as to eliminate pejorative references to "deviate" sexual intercourse. ${ }^{96}$

Among other modernizations in the definition and grading of offenses that can be characterized as noncontroversial in view of the substantial concurrence of S. 1 with the Commission Code are the following. The distinctions between first and second degree murder, based on "deliberation" and "premeditation," which centuries of experience have shown to operate haphazardly and even perversely, will disappear, ${ }^{97}$ as will arbitrary limits on the types of provocation that suffice to reduce a homicide to the level of manslaughter..$^{98}$ The new federal code will be shorn of antiquated and unenforceable morals legislation like the provision penalizing seduction of feniale passengers on steamboats, regardless of age or consent, by "solicitation or the making of gifts or presents." 99 In place of the present federal rape statute, ${ }^{100}$ which authorizes life imprisonment or death without discriminating between forcible ravishment by a stranger and intercourse between "dating" couples who may have been engaging in sexual intimacies just short of intercourse, the new federal code will reserve extreme penalties for the former situation. ${ }^{101}$ It will also treat violent imposition of

92. See text accompanying notes $225-28$ infra.

93. Compare S. $1 \S 1501$ with CoMmission Code $\$ 1501$ ("person" substituted for "citizen," which the Brown Commission accepted from existing law, 18 U.S.C. \$§ 241, 242 (1970)). See also 2 SUBCOMMITTEE REPORT 465-70.

94. 2 SUBCOMMITTEE REPORT 465-70.

95. S. 1 \& 1504; see 2 SUBCOMMITTEE REPORT 482.

96. Compare S. 1 \$\$ 1641 (rape), 1642 (sexual assault) and 1646 (general provisions) with Commission CODE $\$ \S 1641$ (rape), 1643 (aggravated involuntary sodomy), 1642 (gross sexual imposition) and 1644 (involuntary sodomy).

97. Commission CODE $\$ 1601 ; \mathrm{S} .1 \S 1601$.

98. CoMmission CODE $\S 1602 ;$ cf. S. 1 §§ 1601(b)(1), 1602.

99. 18 U.S.C. \& 219 (1970).

100. 18 U.S.C. $\$ 2031$ (1970).

101. Commission CODE $\S 1641$ (two classes of rape); $c f$. S. $1 \S 1641$ (rape is Class C Felony punishable by up to fifteen years imprisonment; however, defendant will face additional liability for battery, kidnapping or other code offenses). See also Model Penal Code § 213.1 (Proposed Official Draft, 1962); 2 SUBCOMMITTEE REPORT 592-95. 
homosexual relations in a manner parallel to the rape of a female by a male. ${ }^{102}$ The federal government will withdraw from its Victorian pretension to police the private sexual behavior of adults; the purview of the Mann Act $^{103}$ will be limited to substantial commercial operations. ${ }^{104}$

\section{Sentencing}

Sentencing is a third major reform front on which S. 1 advanced in the direction marked out by the Brown Commission. It did not advance far enough. It was primarily marred by retention of a retributive emphasis found in existing law. Thus, sentencing remains a central controversy between proponents and opponents of S. 1 , as will be shown below. ${ }^{105}$ Nevertheless, it is important to recognize the areas of agreement. To the extent that such consensus has been achieved, a new domain of civil liberties has been staked out. The most important sectors of this new domain are:

1. Grading. Each serious offense will be divided into several degrees, reserving the most severe penalties for aggravated forms of the offense.

2. Specially dangerous offenders. The maximum sentence for each grade will be available only if the defendant is a dangerous recidivist, a professional criminal or a mental deviate, or if he employs firearms or bombs in carrying out the offense. ${ }^{106}$

3. Consecutive or cumulated sentences. Harsh and arbitrary cumulation of sentences will be minimized not only in the case of multiple mail fraud charges, ${ }^{107}$ but also where multiple distinct offenses are involved. ${ }^{108}$ In principle, repetition of offenses is to be treated as an aggravating factor within the statutory maximum for the grade, as provided in paragraph 2 above. No longer will a burglar who is implicated in five or ten burglaries be theoretically subject to five or ten times the fifteen-year maximum for burglary. ${ }^{109}$ Instead, based on the severe nature and circumstances of the offense and the character of the defendant, he becomes one of the iminority

102. COMMission CODE $\S \S 1643,1644 ;$ S. 1 \$ 1645 (unlawful sexual contact is an offense two grades below that of the corresponding offense under the rape sections).

103. 18 U.S.C. $\S \S 2421-2424$ (1970).

104. Сомmission CODE $\S 1841$ (promoting prostitution); S. $1 \S 1843$ (conducting a prostitution business).

105. See Part IV. C. infra.

106. Compare Commission CODE $\$ 3202$ with S. 1 \$ 3202(b).

107. See notes $72-74$ supra and accompanying text.

108. If multiple terms of imprisonment are imposed on a defendant at the same time or if a term is imposed on a defendant who is already subject to an undischarged term of imprisonment, the terms will run concurrently unless the court orders that they be served consecutively. Compare Commission CODE § 3204 with S. 1 § 2304.

109. See 18 U.S.C. § 2111 (1970). 
of burglars who can be given a sentence as high as fifteen years. ${ }^{110}$ This but reflects the obvious truth that legislatures set fifteen-year maxima precisely for the worst offenders.

The existing rule permitting cumulation of sentences has a number of baneful effects. It permits gross inequalities in sentencing, since some judges abuse the discretion to cumulate while most follow the practice of making multiple sentences concurrent. Unlimited cumulative sentencing is also employed by a minority of judges to frustrate the legislative will with regard to parole. A judge who is unsympathetic to parole generally or in a particular case can give a sentence so long that the convict will not become eligible for parole until he has fully served the maximum jail sentence that was appropriate for the offense. The judge thus succeeds in equating the minimum with the maximum, imposing, in effect, a flat sentence, whereas Congress has declared that the minimum for parole eligibility shall not exceed one third of the maximum. ${ }^{111}$

4. Penal policy; legislative criteria for sentencing; review of sentence. For the first time in the history of the country federal law will declare the purposes of the penal system, ${ }^{112}$ provide guidelines for the exercise of sentencing discretion, ${ }^{113}$ and direct the appellate courts to review at least the longer sentences as a check against abuse of discretion by sentencing judges. ${ }^{114}$ In each case there are shortcomings in the S. 1 provisions, but that should not obscure the central fact that progress beyond existing law was embodied in the bill.

5. Parole. The new federal code will by common consent eliminate the absurdity of present law which in effect prescribes the shortest period of parole supervision for the most dangerous convicts. This paradox results from the traditional view that parole is simply an act of mercy that permits service of part of the sentence outside the prison walls. ${ }^{115}$ A parole board is

110. Under Commission CODE $\S 1711(2)$, burglary is a Class B Felony, the maximum term for which is fifteen years. Id. $\$ 3201(1)(b)$. Under S. 1 \$1711(b) burglary is a Class C Felony punishable by up to fifteen years imprisonment, $i d$. $\$ 2301(b)(3)$, unless the offender is deemed dangerous, in which case the maximum term is increased to twenty-five years. Id. $\$ 2301$ (c).

111. 18 U.S.C. $\$ \$ 4202,4208$ (1970).

112. See Commission Code $\S 102$ (derived from Ill. ANn. Stat. ch. 38, \$\$ 1-2 (Smith-Hurd 1972); N.Y. PENAL LaW § 21 (McKinney 1970)); S. 1 \$ 101.

113. See COMmission CODE $\$ 3101 ;$ S. 1 \& 2102(a). See also Commission Working PAPERS $1267-69,1300,1306-07$.

114. Compare Commission CODE Comment, at 317 (proposed revision of 28 U.S.C. § 1291 for appellate review of sentences) with $S .1$ \$ 3721-3726. As for requiring judges to provide written justifications for sentencing actions, see COMMISSION CODE $\$ \S 3201(3)$ (fixing a minimum term), 3202(4) (imposing specially long terms for dangerous offenders) and 3204(5) (exercising the limited discretion to make sentences consecutive). S. 1 does not require these written justifications.

115. Under current law a term of parole extends from release until the expiration of the maximum term specified in the original sentence. 18 U.S.C. $\$ 4203$ (1970). Contra, 21 U.S.C. 
likely to keep the most dangerous prisoners inside the walls until they have fully served their sentence. In that event, no part of the sentence remains to be served under parole supervision. In contrast, the most promising prisoners will be released early and will have long years of unexpired sentence to serve on parole. S. 1 follows the Brown Commission lead in abolishing this irrational correction program, providing instead that all prisoners serving substantial sentences shall eventually be released under parole for periods roughly proportionate to the period of actual confinement. ${ }^{116}$

In speaking of "consensus reforms" in this section of the Article, I may be overstating the matter. One sector of the community appears to have rejected reform: the organized federal judiciary. Speaking in the name of the Judicial Conference of the United States, Chief Justice Burger addressed a letter to Congress opting in favor of "existing laws," on the ground that having to adapt their jury charges to new laws would be an "enormous burden" on federal judges. ${ }^{117}$ That this institutional and personal concern of

\$ 841(b) (1970) (special, longer parole terms apply for narcotics offenses that extend beyond the term of imprisonment). See also 3 SUBCOMMITTEE REPORT 1047.

116. Compare COMmission CODE $\S \S 3201(2), 3403(2)$ with S. $1 \S \S 2303,3834$. There are radical differences between the two approaches to the problem. The Commission envisioned the parole period as falling inside the maximum sentence legislatively authorized. S. 1 makes parole an addition to the legislatively prescribed term or any shorter term imposed by the sentencing judge, and permits the Parole Commission to set the duration of parole within specified statutory limits. S. $1 \S 3834$. This makes it difficult to compare the general level of severity of the two codes, because the legislative maxima do not reflect differences in $\max$ imum period of confinement. The Commission's maxima must be reduced by the period of mandatory parole, whereas an $\mathrm{S} .1$ sentence may have to be served out in prison, to be followed by as much as five years of parole, which of course carries a contingent threat of further imprisonment for behavior that is not necessarily criminal but merely violative of the conditions of parole.

Substantial liberalization of S. 1's original parole provisions was incorporated in the January 15, 1975 version. See STAFF OF SENATE Comm. ON THE JudiciaRY, 94TH CoNG., 2D SESS., REPORT ON CRIMINAL JUSTICE REFORM ACT OF 1975 1077-78 (Comm. Print 1976) (draft committee report accompanying the revised bill).

117. Letter from Chief Justice Warren Burger to Congress (May 12, 1976). The letter reads as follows:

By direction of the Judicial Conference of the United States I transmit to you herewith a report unanimously approved by the Judicial Conference at its session on April 7, 1976, concerning H.R. 10850 and related bills pertaining to the proposed new Federal Criminal Code. This report deserves careful study by your committee.

Permit me to call attention again to the searching discussion at the earlier Conference meeting in which the essence of the Conference view was that the enactment of this Code, as distinguished from a less complex recodification of existing laws, will impose an enormous burden on all federal courts for a long period in the future. Just how long, no one can safely predict. This will arise from the need to restructure jury instructions for every new definition of criminal acts, in order to comport with the new Code, and from the appellate review of elements of those instructions by each of the Courts of Appeals and ultimately by this Court.

I feel obliged also to call attention again to the unanimous resolution of the Conference of Metropolitan Chief Judges opposing the enactment of the proposed new Code. Its members are the 23 Chief Judges of the larger federal districts which together are responsible for more than one-half of all cases in the federal courts.

See Denniston, Did Burger Letter Help Kill Criminal Code Reform Bill?, Washington Star, July 27, 1976, at A-2, col. 1. 
judges should be treated by them as the paramount consideration, blocking not only current reform efforts but also any future pervasive or systematic reform, is astonishing and disturbing. Perhaps, however, the Burger letter has been misunderstood. The Judicial Conference of April, 1973 accepted the notably favorable report of its Committee on the Administration of the Criminal Law ${ }^{118}$ and subsequently transmitted it to Congress. The Conference also "[a]pproved in principle the proposal for a new or amended Federal Criminal Code," 119 and directed the Committee to continue its close study of particular provisions. The continuing labors of the Committee were noted in reports of subsequent proceedings of the Conference. ${ }^{120}$ Although Committee reports had referred to the task of revising jury instructions, it was only in the Report of the Judicial Conference of September, 1975, that this consideration suddenly assumed major significance. In a paragraph preceding the usual Conference note of the Committee's on-going studies, the Judicial Conference declared that its "views . . . as previously reported, reflected opposition to this [S. 1] legislation." 121 This statement is somewhat ambiguous in light of the fact that no explicit opposition appears in earlier Judicial Conference reports ${ }^{122}$ nor in the Judicial Conference

118. We express general approval of the objectives sought and methods utilized in the reform of the federal criminal laws by all three approaches [i.e., Brown Commission, S. 1, and a Department of Justice draft introduced as S. 1400]. The President and distinguished members of Congress have commended the Brown Commission for its magnificent endeavors. The work of the Commission demonstrated not only keen insight and scholarship, but represented an effort to comply with the spirit of criminal law reform begun by the American Law Institute in 1952 and completed ten years later with the publication of the "Proposed Official Draft" of the Model Penal Code.

Report of the Committee on the Administration of the Criminal Law of the Judicial Conference of the United States (Apr. 5, 1973).

119. Judicial Conference of the United States, Report of Proceedings 15 (April 5-6, 1973).

120. Judicial Conference of the United States, Report of Proceedings 78-79 (Sept. 13-14, 1973); Judicial Conference of the United States, Report of Proceedings 22 (March 7-8, 1974); Judicial Conference of the United States, Report of Proceedings 56-57 (Sept. 25-26, 1975); Judicial Conference of the United States, Report of Proceedings 12 (April 7, 1976).

121. The paragraph, derived from the Report of the Committee on the Administration of the Criminal Law read as follows:

The views expressed on S. 1, as previously reported, reflected opposition to this legislation on the ground that it contemplates unnecessarily sweeping redefinition of all federal crimes and will require, among other things, (a) that every district judge will he required to restructure and formulate new jury instructions to replace those which have evolved on a literal "trial and error" basis for well over 100 years; (b) that new instructions for newly defined crimes must then literally "run the gauntlet" of courts of appeals; and (c) that ultimately the Supreme Court will be obliged to review numerous cases to pass finally on the adequacy of the instructions required by the new code. In the present state of overcrowded dockets at every level, the new and complex burdens that S. 1 will impose on the federal courts are incalculable. The Conference nevertheless continues to comply with congressional requests for comments on specific parts of $S .1$.

Judicial Conference of the United States, Report of Proceedings 56 (Sept. 25-26, 1975). One does not know which "views . . . previously reported" are referred to, nor what is meant by "reflected opposition" as distinguished from "reflected concern" or "directly opposed."

122. The only indication that there was a divergence of viewpoints on $S .1$ can be seen in the 
Report of April 7, 1976, where the federal criminal code and the work of the Committee are discussed. ${ }^{123}$ One can only hope that improvement in the law has not been rejected by the federal judges on the ground that they are too busy. Certainly state experience with recently enacted comprehensive codes offers no support for the view that judges will be intolerably burdened during the period of transition from the archaic to the modern. ${ }^{124}$

\section{HUBRIS AND REPRESSION ON THE RIGHT}

Federal penal reform foundered in the Ninety-fourth Congress despite consensus on many major advances. This temporary check was due to the determination of conservatives to have their bill carry numerous "hardline" features that the Brown Commission had rejected, and to demagogic opposition from the Left, directed not only against the repressive features of S. 1 but against S. 1 in its entirety.

The first destructive element of the hubris of the Right was overambition. Instead of restricting S. 1 to a substantive criminal law with technical amendments necessary to fit the project into the United States Code, the Senate Subcommittee chose to recapitulate, with modifications, the entire range of the criminal justice system. Thus, S. 1 has sections on investigative and law enforcement authority generally, ${ }^{125}$ wire-tapping ${ }^{126}$ and witness immunity, ${ }^{127}$ extradition, ${ }^{128}$ venue, ${ }^{129}$ counsel for the indigent, ${ }^{130}$ bail, ${ }^{131}$ treatment of juveniles and the insane, ${ }^{132}$ pre-trial procedure, ${ }^{133}$ rules of

Report of the Proceedings of the Judicial Conference of the United States for March 6-7, 1975. Acting on the report of the Committee on the Administration of the Criminal Law and analyzing various provisions of $S$. 1, the Conference made the following statement:

In discussing S. 1 members of the Conference again expressed great concern that if this legislation is enacted, new forms of jury instructions will be required and appellate courts will be called upon to review the correctness of new instructions and that all of these factors will have a serious impact on the work of all federal courts.

Members of the Conference continued to express the view that a traditional recodification of the existing statutes would serve all the purposes of a completely new code redefining federal crimes. Some expressed the view that if such a comprehensive code is to replace all present federal criminal statutes, the present time was most inappropriate in view of the rising caseloads, new classes of litigation and the adjustments necessary to meet the Speedy Trial Act over the next five years.

Judicial Conference of the United States, Report of Proceedings 19-20 (March 6-7, 1975).

123. Judicial Conference of the United States, Report of Proceedings 12 (April 7, 1976).

124. See note 10 supra and accompanying text.

125. S. $1 \S 3001-3018$.

126. Id. $\$ \S 3101-3109$.

127. Id. $\$ \$ 3111-3115$.

128. Id. §§ 3211-3217.

129. Id. $\S \S 3311-3313$.

130. Id. $\$ \S 3401-3405$.

131. Id. $\$ \$ 3501$ et. seq.

132. Id. $\$ 3601$ et. seq.

133. Id. \$\$ 3701-3702. 
evidence, ${ }^{134}$ forfeiture proceedings, ${ }^{135}$ the internal operations of the Parole Commission, ${ }^{136}$ and the establishment of a new Victim Compensation Fund. ${ }^{137}$ Most of this was unobjectionable and some was even progressive, but the bill was distended to become an intimidating document of over 750 pages. ${ }^{138}$ Given the provocative character of the Subcommittee's proposed innovations relating to substantive law, opponents could be forgiven for viewing with suspicion these extra hundreds of dense pages represented as largely restatements of existing law, but never having been reviewed by the Brown Commission. In short, the opposition's target had been broadened and rendered more vulnerable.

The major departures from the Commission Code proposed in S. 1, while disastrous from the point of view of liberal democratic policy, were perhaps most objectionable because they gravely impaired the chances of getting any reform at all enacted. While disagreement as to capital punishment and gun control could hardly be avoided, a review of conservative insistence on other issues such as censorship and the defense of insanity serves to illustrate the excess of zeal that has so endangered the reform program.

\section{A. The "Official Secrets" Provisions}

Recollection of the Pentagon Papers case and continuing paranoia in the White House about "leaks" to the news media led to the inclusion in S. 1 of the notorious provision making unauthorized disclosure of "classified information" a felony. 139 Even after being watered down from earlier versions, ${ }^{140}$ the proposal for an "Official Secrets Act," as it came to be called in the press, was horrendous. Classified information was defined as any information "marked or designated" pursuant to a statute or regulation

134. Id. $\$ \S 3711-3715$.

135. Id. $\S \S 4001-4005$.

136. Id. $\S \S 3831-3837$.

137. Id. $\$ \$ 4111-4115$.

138. The facts that approximately 500 pages of the bill consisted of conforming amendments raising no separate substantive issues, and that tax bills, as well as other complex legislation, are often of comparable length did not moderate the opposition's exploitation of the awesome size of S. 1. See notes 296, 299 infra and accompanying text. See also Part VII of this Article.

139. S. $1 \$ 1124$. The section provided that:

A person is guilty of an offense, if, being or having been in authorized possession or control of classified information, or having obtained such information as a result of his being or having been a federal public servant, he knowingly communicates such information to a person who is not authorized to receive it.

Id. $\S 1124(\mathrm{a})$. Both present law and the Commission Code, of course, contain provisions punishing the betrayal of certain narrowly defined classes of secrets such as diplomatic or military codes, 18 U.S.C. $\S 798$ (1970), nuclear technology, 42 U.S.C. $\S \S 2274,2298(b)$ (1970) and basic defense plans and weaponry, 50 U.S.C. $\S 783$ (1970). See COMMIssion CoDE $\S 1114$.

140. The Subcommittee yielded to some public and senatorial criticism by adding a provision to section 1124 excepting from its purview the recipients of unlawfully disclosed classified material. 2 SUBCOMMITTEE REPORT 244-45; see S. 1 \& 1124(b). 
as "requiring a specific degree of protection against unauthorized disclosure for reasons of national security." 141 Thousands of underlings in the civil and military establishments would thus be authorized to impose restraints on the right of the public to know what the government was doing, and this at a time when the country was moving in the opposite direction by enacting "sunshine laws" to assure public access to information about bureaucratic decision-making processes. ${ }^{142}$ That the information "was not lawfully subject to classification" was declared to be no defense, ${ }^{143}$ but the Subcommittee sought to mollify critics with putative safeguards against prosecution for disclosing "classified information" which should never have been so classified or which should long since have been declassified. Prosecution was to be barred unless a government agency had been established to review classifications. ${ }^{144}$ The head of that agency, the head of the classifying agency, and the Attorney General would all have to certify prior to the return of an indictment that the information had been lawfully classified. ${ }^{145}$

A final striking bit of overreaching was the explicit penalizing of "unauthorized disclosure" even to members of Congress; only a "lawful demand" (a subpoena?) from a "regularly constituted"' congressional committee was acceptable as an "affirmative defense," i.e., with the burden of proof on the defendant. ${ }^{146}$ The spectacle of criminal prosecution of an honest and patriotic civil servant who had revealed shenanigans in defense contracting to a Congressman was alone sufficient to generate and to justify the revulsion that greeted section 1124. Unfortunately, that revulsion was easily extended to S. 1 generally, as the news media of the United States turned this into the central issue in the legislation.

A barbed bait was thrown to the press in the form of a provision that the receiver of an unauthorized disclosure could not be prosecuted as an accomplice of the discloser or for conspiracy with or solicitation of the

141. S. $1 \S 1128(\mathrm{~b})$.

142. See, e.g., Freedom of Information Act, 5 U.S.C.A. $\$ 552$ (Supp. 1976).

143. S. 1 1124(e). However, a defense was accorded where a defendant "had attempted to obtain the declassification of the information and had exhausted all administrative remedies . . . " Id. $\S 1124(\mathrm{~d})(2)(\mathrm{e})$. Even such a mythically persistent dissident bureaucrat would have no defense of illegality if anyone, for example, a news reporter, gave him "anything of value" (legal expenses?) in return for disclosure. Id. §1124(d)(2)(B). Moreover, assuming all other hurdles were overcome, the accused still had the burden of proving that the classification was indeed unlawful, thus reversing the presumption of innocence with regard to the central issue of culpability.

144. Id. $\S 1124(\mathrm{c})$. The Subcommittee thought that the Interagency Classification Review Committee, an existing agency established by Exec. Order No. 11,652, 3 C.F.R. $\$ 339$ (1974), satisfied this requirement. See 2 SUBCOMMITTEE REPORT 246.

145. S. $1 \S 1124$ (c)(2).

146. Id. $\S 1124(\mathrm{~d})(1)$. It should be noted that this narrow exemption derives from existing law, 18 U.S.C. $\$ 798$ (c) (1970), and from section 1114(4) of the Commission Code. Both of those sections, however, deal with narrow categories of "classified" information, with respect to which narrow exemptions might be considered appropriate. 
principal offender. ${ }^{147}$ But the Subcommittee Report made it clear that prosecution of newsmen for illegal receipt of "national defense information," whether classified or not, would be possible under proposed section 1123(a) (2)(b) which required a person in unauthorized possession of national defense information to "deliver it promptly to a federal public servant who is entitled to receive it." 148 The American press did not take the bait. Both the press and the public perceived that first amendment values were being subverted not only by direct threats to newsmen but also by efforts to choke off sources within the bureaucracy. Many Americans believe that "leaks" from the bureaucracy are a bastion of popular control of government and, therefore, of democracy and liberty. Suspicion of the "Official Secrets Act" was further intensified by common knowledge that intentional leaks relating to vital elements of international policy and security are a common feature of "news management" by the highest executive officers.

S. 1's incursions on freedom of speech were not confined to section 1124. They were found also in the treatment of espionage, sedition and conspiracy, theft of information, obscenity, and "impairing a government function." 149

\section{B. Abolishing the Insanity Defense}

Repeal of the insanity defense in S. 1 is another example of jeopardizing progress by encumbering the bill with impolitic and provocative features. Insanity was recognized as a defense only if the mental defect caused a lack of "the state of mind required as an element of the offense charged." 150 This means, for example, that a defendant who cut his wife's throat would be acquitted if he was so crazy as to believe that he was merely slicing cheese, for then he would not have had the intent to kill required for murder. But if he insanely supposed that his wife was poisoning him, or that God required him to dispose of his wife, he would be convicted. Present law, approved not only by the Brown Commission ${ }^{151}$ but also by the American Law Institute ${ }^{152}$ and all of the federal courts of appeal, ${ }^{153}$ acquits the defendant (with appropriate provision for civil constraint) if he "lacks substantial capacity to appreciate the criminality of his conduct or to con-

147. Id. \& 1124(b). See note 140 supra.

148. S. 1 \& 1123(a)(2)(b); see 2 SUBCOMMITTEE REPORT 244-45. Although this offense is a carryover from existing law rather than an innovation by S. 1, see id., the cover of the ACLU pamphlet STOP S-1 carried the statement: "Did you read the Pentagon Papers in your newspaper? S. 1 could put the paper's editors in jail." ACLU, STOP S-1 (undated pamphlet).

149. The subject is elaborated on in Schwartz, supra note 4, at 3203.

150. S. $1 \S 522$.

151. COMMISSION CODE $\S 503$.

152. MODEl PENAl CODE $\& 4.01$ (Proposed Official Draft, 1962).

153. See 1 COMMISSION WORKING PAPERS 230-34. 
form his conduct to the requirements of law."154 Failure to accord a defendant such a defense is to ignore the relevance of moral responsibility and power of choice to guilt. Further, it serves to apply the gravest sanctions of the system of deterrence, the criminal law, against people who are undeterrable. In effect, S. 1 abolished the defense of insanity, since lack of the required criminal intent would be a defense under the Code whether or not the defendant was insane. Thus $S .1$ treated the sane and the insane alike. This radical departure from fundamental notions of culpability in crime follows two decades of intense consideration of the subject by the courts and commissions, resulting in a remarkable unanimity among legislators and courts in favor of the Commission's position. ${ }^{155}$

It is far from clear that the formula proposed in S. 1 would even accomplish the proponents' purpose to exclude a perplexing issue from trial by jury, to limit the role of psychiatrists and to increase the number of murder convictions. ${ }^{156}$ This is so because section 522 left untouched the requirement of proving criminal intent, and it recognized that mental illness may negate criminal intent. Psychiatrists, then, would assuredly be found to give expert opinions that homicidal intent was precluded by the defendant's insanity. Opposing experts would be marshalled. Juries would continue to be bombarded with confounding testimony. The only difference would be that judges would instruct on impairment of intent rather than impairment of the defendant's ability to conform to the law. Juries would continue to convict or acquit in response to inarticulate feelings of justice. It is true that many of the foregoing unsatisfactory features are also found in trials of the insanity issue under present law, but if they cannot be eliminated, and are instead only aggravated by the S. 1 proposal, there is surely no justification for a radical innovation that calls for disregarding issues of culpability.

\section{Harsh Sentencing}

Sentencing is the core of a criminal code, and it is here that the contrasts between S. 1 and the Commission Code were most pervasive and significant. Ironically, this aspect of the reform, directly concerned with deprivation of liberty and overbroad official discretion, received the least attention from civil liberties organizations and the press. Perhaps this is due to the fact that sentencing issues are not concentrated in a single, highly visible provision, and can be appreciated only by analyzing sections dealing with maximum and minimum terms, probation, parole, consecutive sen-

154. COMmission CODE $§ 503$.

155. The proposed abolition had some academic, bar association and psychiatric support, see 2 SUBCOMMITTEE REPORT 112-13, and had indeed been favored by the Brown Commission's consultant in this area. 1 COMMISSION WORKING PAPERS 247-54.

156. See 2 SubCOMMITTEE REPORT 109-11. 
tences, special sentences for dangerous offenders and appellate review of sentence.

The sentences prescribed in S. 1 for particular offenses were not always higher than those recommended by the Brown Commission. ${ }^{157}$ Looking at a single provision, one might conclude that $\mathrm{S} .1$ was sometimes more lenient than the Commission Code. While S. 1 provided for parole eligibility after the prisoner had served one-quarter of his term, ${ }^{158}$ for example, the Commission contemplated service of one-third of the imposed prison term. ${ }^{159}$ But these appearances were deceptive, as the following discussion will show.

1. Excessive maximum terms. The key to comparison of the maximum terms provided in S. 1 and the Commission Code is to remember that the maxima prescribed in S. 1 were supplemented by extended terms for specially dangerous offenders ${ }^{160}$ and by parole terms of as much as five years. ${ }^{161}$ In contrast, the maxima set forth in the Commission Code include a portion reserved only for specially dangerous offenders ${ }^{162}$ as well as a "mandatory parole" term, that is, the terminal portion of the sentence that is to be served outside prison (absent parole violation). ${ }^{163}$ An example will help to clarify the difference between these two sentencing schemes.

Perjury was a Class D felony under S. $1^{164}$ and a Class $C$ felony under the Commission Code. ${ }^{165}$ Each of these categories entailed a stated maximum of seven years. ${ }^{166}$ To the seven-year maximum under $S .1$ there would have to be added the possibility of a seven-year extended sentence for recidivists, professional criminals or other specially dangerous types, ${ }^{167}$ and a parole term which might be as much as five years. ${ }^{168}$ The S. 1 maximum, therefore, would be nineteen years if calculated on the same basis as sentences under the Commission Code. A specially dangerous perjurer convicted under the Commission Code, on the other hand, would be subject to a maximum total sentence-including extended sentence and parole- of seven years. 169

157. Compare S. $1 \S \S 1641,2301$ (b)(3) (fifteen years for rape) with Commission CODE $\$ \S$ 1641,3201 (1)(a) (thirty years).

158. S. 1 \& 2301(d).

159. COMMISSION CODE § 3201(3).

160. S. $1 \S \S 2301$ (c), 2302(b).

161. Id. $\S 3834(\mathrm{~b})$.

162. COMMISSION CODE $\S 3202$.

163. Id. $\S 3201(2)$.

164. S. 1 \& 1341(b).

165. COMMISSION CODE $\S 1351(1)$.

166. S. 1 § 2301(b)(4); COMMISSION CODE § 3201(1)(c).

167. S. $1 \S 2301(\mathrm{c})$.

168. Id. $\S \S 2303(\mathrm{a}), 3834(\mathrm{~b})$.

169. If the convicted perjurer were not a specially dangerous offender, the maximum sentence he could be given under the Commission Code would be five years. COMMISSION CODE $\S 3202(1)$. The comparable maximum under S. 1 would be twelve years-a seven-year maximum prison term and a five-year maximum term of parole. S. $1 \$$ 2301(b)(4), 3834(b). 
Additional differences can be identified by examining the parole provisions under the two codes. A perjurer convicted under the Commission Code and sentenced to the seven-year maximum could be released by the Parole Board after serving one year, ${ }^{170}$ should be released as soon as the Board believes that no purpose is served by continued confinement, ${ }^{171}$ and must be released on parole after serving four years and eight months. ${ }^{172} \mathrm{On}$ the other hand, the perjurer convicted under S. 1 and sentenced to the fourteen-year maximum prison term might have to serve a minimum term in prison of three and one-half years. ${ }^{173}$ While the Parole Commission would have to consider the parole of the prisoner at the end of such maximum term (or after each year of imprisonment if no term of parole ineligibility were set), ${ }^{174}$ it would not be required to release him until he had served out all fourteen years. ${ }^{175}$

The simplest way to ameliorate the harsh $\mathrm{S}$. 1 maxima would be to provide that the parole component of the sentence be deducted from those maxima rather than added to them. Similarly, the extended term for specially dangerous offenders should not be added to the stated maximum, but rather should be conceived as a portion of the ordinary maximum reserved for the exceptionally dangerous, as under the Commission Code. ${ }^{176}$ The adoption of the same principle in S. 1 would tame the ferocity of S. 1's maxima, and would comport with the obvious congressional intent expressed in existing maxima, namely that they go much higher than is appropriate for the ordinary offender.

2. Probation discretion. S. 1 directed the sentencing judge to consid-

170. COMMISSION CODE $\S 3402(1)$.

171. The Commission Code provides that, after the first year of imprisonment, a prisoner sentenced to more than three years in prison

shall be released on parole, unless the [Parole] Board is of the opinion that his release should be deferred because:

(a) there is undue risk that he will not conform to reasonable conditions of parole;

(b) his release at the time would unduly depreciate the seriousness of his crime or undermine respect for law; line; or

(c) his release would have a substantially adverse effect on institutional discip-

(d) his continued correctional treatment, medical care or vocational or other training in the institution will substantially enhance his capacity to lead a law-abiding life if he is released at a later date.

Id. It should be noted that a sentencing judge could set a minimum prison term in certain circumstances. Id. §3201(3).

172. Id. \$3402(3). The section provides in part that: "The parole component of [a] maximum term shall be . . one-third for terms of nine years or less . . ." Id. \$3201(2).

173. "The authorized terms of imprisonment for felonies that may be required to be served prior to eligibility for parole are not more than one-fourth the term authorized . . . " S. 1 § 2301(d).

174. Id. §§ 3831(b), (d).

175. Id. §3831(c).

176. COMMission Code $\$ 3202(1)$. See note 169 supra. 
er a fairly conventional list of factors relevant to the grant or denial of probation, but, unlike the Commission Code, emphasized those factors pointing towards the "need" for imprisonment for retributive or deterrent purposes. ${ }^{177}$ Notably, S. 1 failed to state that prison should be resorted to only if the judge were satisfied that it was the more appropriate disposition. Such a preference for probation had been espoused by the Brown Commission, ${ }^{178}$ the American Law Institute ${ }^{179}$ and the American Bar Association Project on Standards for Criminal Justice. ${ }^{180}$ The omission of a stated preference in S. 1 meant that no judge would have to face up to this crucial issue, and that different judges would operate on different assumptions as to where the "burden of proof" lay on the issue of imprisonment versus probation. The failure to declare legislative policy on this point was aggravated by excluding from appellate review the refusal of a judge to grant probation, except where he imposed a long prison sentence. ${ }^{181}$

The probation provisions of $S .1$ were defective in two other important respects. In contrast to the Commission Code, which contained no exclusions from eligibility for probation, ${ }^{182} \mathrm{~S} .1$ excluded from probation all Class $\mathrm{A}$ offenders, ${ }^{183}$ criminals who used guns, ${ }^{184}$ and drug offenders. ${ }^{185}$ The main effect of these provisions would be to vest discretion as to probation, ordinarily a judicial function, in the prosecutor, who would make the effective decision regarding eligiblity for probation when he selected the specific charges to bring and the plea bargains to accept.

3. Consecutive sentencing. The Brown Commission's provisions on consecutive sentences embodied three important principles: (1) consecutive sentences were flatly precluded in certain instances; ${ }^{186}$ (2) even where

177. S. $1 \S 2102(a)$ directs the sentencing judge to consider:

(1) the nature and circumstances of the offense and the history and characteristics of the defendant; and

(2) the need for the sentence imposed:

(A) to reflect the seriousness of the offense, to promote respect for law, and to provide just punishment for the offense;

(B) to afford adequate deterrence to criminal conduct;

(C) to protect the public from further crimes of the defendant; and

(D) to provide the defendant with needed educational or vocational train-

ing, medical care, or other correctional treatment in the most effective manner.

178. Commission CODE $\S 3101(2)$ :

The court shall not impose a sentence of imprisonment upon a person unless, having regard to the nature of the circumstances of the offense and to the history and character of the defendant, it is satisfied that imprisonment is the most appropriate sentence for the protection of the public ....

179. Model Penal Code $\$ 7.01$ (Proposed Official Draft, 1962).

180. AMERICAN Bar Association Project on Standards for CRIMINal Justice, STANdards Relating to Probation \$ 1.3 (Approved Draft, 1970).

181. S. $1 \S 3725(\mathrm{a})(1)(\mathrm{B})$.

182. COMMISSION CODE $\$ 3101(1)$.

183. S. 1 \& 2101(a).

184. Id. § $1823(\mathrm{~b})$.

185. Id. \& 1811(b).

186. Consecutive sentences could not be imposed for crimes whose prohibition protects the 
permitted, there would be a low ceiling on the aggregate of consecutive sentences; ${ }^{187}$ and (3) the use of consecutive sentences was in any event confined to cases where "exceptional features" required such action "for reasons which the court shall set forth in detail." 188

The corresponding provisions of S. 1 did not deal adequately with any of these principles. A conspiracy sentence could be added to a sentence for the target substantive offense. ${ }^{189} \mathrm{~A}$ sentence for possessing a gun during the commission of a crime not only could but had to be made consecutive, ${ }^{190}$ even though the crime itself carried a high maximum penalty, as in the case of robbery, because it commonly involves use of weapons.

4. Parole discretion. Under S. 1400 , the Nixon Administration bill which was eventually consolidated with S. 1, the Parole Commission would have been required to make five difficult findings before parole could be granted: that release would not be inconsistent with "just punishment"; that it "would not undermine the affording of adequate deterrence"; that there would be no "undue risk" of further criminality; that it would not adversely affect institutional discipline; and that further "correctional treatment" would not improve the prisoner's "capacity to lead a law-abiding life."191 Proof of a negative is notoriously difficult; proof of these negatives verges on the impossible, for they involve such issues as what constitutes "just punishment" or "adequate deterrence," as well as predictions of future behavior.

Accordingly, the parole provisions of S. 1 presented one of the central issues in reform of the federal criminal law, since they bore on length of confinement, on the degree to which Congress would prescribe guidance for one of the most important yet least reviewable administrative decisions in government, and on the fundamental principle that detention is not to be imposed or prolonged unless soneone is satisfied that it serves a purpose. In contrast, under S. 1, detention would be prolonged until sonieone was satisfied that it served no purpose. The fundaniental principle of equal justice was violated by the formula that parole "may" be granted but need

same interest with varying degrees of specificity, crimes which are part of a single course of conduct or crimes which involve substantially the same criminal objective. COMMISSION CODE § 3204(2)(c).

187. Generally, the aggregate of consecutive sentences could not exceed the statutory maximum for an offense of the next level above any offense covered by the sentence. Id. $\S$ 3204(3). So also, consecutive sentences were barred where one offense was "included" in the other, id. $\$ 3204(2)(a)$, or was only an attempt, solicitation, or conspiracy to commit the other. Id. §3204(2)(b).

188. Id. \& 3204(5).

189. This conclusion is reached by noting the absence of any limitation on such a sentence in the section on multiple sentences. See S. 1 \& 2304.

190. Id. § 1823(b).

191. S. 1400 , 93d Cong., 1st Sess. $\S 4202$ (d) (1973). These provisions, with some modifications, were incorporated in S. 1 \& 3831 (c). 
not be, even when the difficult proof requirements are met, so that prisoner A stays in jail while indistinguishable prisoner B goes free. ${ }^{192}$ It is noteworthy that the Parole Commission and Reorganization Act of 1976 mandates parole (1) when release would not "jeopardize the public welfare," "depreciate the seriousness" of the offense, or "promote disrespect for the law," and (2) after service of two-thirds of sentences upwards of five years unless the Parole Commission determines that the prisoner has seriously and frequently violated institution rules or that there is a "reasonable probability" that he will re-engage in crime. ${ }^{193}$

5. Appellate review of sentence. Under section 3725 of S. 1, a defendant could have his sentence reviewed only in felony cases where the sentence imposed exceeded one-fifth of the authorized maximum. ${ }^{194}$ This would deny review of misdemeanor sentences, although they might involve several years of imprisonment (in the case of multiple misdemeanors), while permitting review of felony sentences involving fines only. It would also deny appeal from prison sentences as long as six years where the authorized maximum was thirty years. If a cut-off is necessary, it ought to be such as to allow review of any sentence beyond six months or a year. In addition, a defendant should be allowed review of a decision denying probation even if he is not allowed to challenge the length of his sentence. The difference between probation and no probation, that is, the decision whether or not the defendant goes to jail at all, is clearly more important than the precise length of sentence. Because of that importance, S. 1 proposed to allow the prosecution to appeal any decision in favor of probation. ${ }^{195}$ A corresponding appeal by the defense of a denial of probation would seem only fair.

S. 1 was overly generous to the government by permitting it to seek review of a sentence whenever a trial judge put a defendant on probation and

192. The Criminal Justice Section of the American Bar Association favored a "presumption for probation," but declined to follow the Brown Commission on the desirability in parole proceedings of a similar preference for release unless the Parole Board believed that continued imprisonment served some public purpose. AmERICAN BAR Association, CRIMINAL Justice Section, Policy Regarding S. 1-The Proposed Federal Criminal Code App. A, at 19, 24 (1975) (report to the House of Delegates). The report misstated the issue in referring to a "presumption . . that all prisoners, no matter how long their sentences, should be paroled at the completion of the first six months." Id. at 24. There is no such presumption. On the contrary, given the criteria including "just punishment," a rational parole board could hardly release serious offenders early in the parole period. The Brown formulation simply recommends that parole thinking be oriented not towards detention unless there is ground for release (the "mercy"-i.e., retributive-approach) but to release unless detention serves some purpose, even the retributive. Moreover, under the Commission Code as well as S. 1, the parole board's decision against parole is not reviewable except on procedural or constitutional grounds, COMMISSION CODE $\S 3406$, thus emphasizing the precatory character of the parole guidance provisions.

193. Pub. L. No. 94-233, § 4206(a),(d), 90 Stat. 223.

194. S. $1 \S 3725$ (a).

195. Id. $\S 3725(\mathrm{a})(2)(\mathrm{B})$. 
whenever he set a prison term below three-fifths of S. 1's high maxima. ${ }^{196}$ This generosity is especially dangerous in view of the authority which S. 1 conferred upon the appellate court to increase a sentence under review upon petition of the government. ${ }^{197}$ Thus, threats by prosecutors to seek review and increase of sentence could be employed to discourage defendants from seeking review.

6. Miscellaneous. The foregoing criticisms call for extensive revision of S. 1's sentencing provisions. In the course of that revision, other improvements should be sought. It would be helpful to incorporate section 2301(a), the general section on sentencing, into a declaration of congressional policy that sentences (both legislative maxima and terms actually imposed) should be related to specified goals. For example, a sentence motivated solely or predominantly by deterrence should normally be quite short; a goal of incapacitation suggests a longer confinement, which may incidentally reflect also some element of "just punishment."198

The concept that terms should be related to the goals of sentencing, whether articulated in section 2301 or elsewhere, would furnish a rationale for deciding how many classes of offenses to set up in the Code. Section 2301 of S. 1 provided nine classes, not counting a tenth provided in effect by the division of Class $\mathrm{A}$ felonies into capital and non-capital categories. There simply are not that niany different useful categories of criminality for sentencing purposes. The Brown Commission proposed six categories, or only five if one sets apart "infractions," a category of offenses for which only fines could be imposed. ${ }^{199}$ Increasing the number of categories is chiefly a reflection of the retributive inipulse; the legislator desires an array of finely-graduated classes of crime to which he can assign particular offenses in accordance with his intuitive assessment of the relative seriousness of the offense. The logical end of this process is the chaos of existing law, under which Congress has established one hundred or more categories of offenses punishable by distinct sentence nraxima, ${ }^{200}$ although concededly most of this present differentiation among offenses is the result of inadvertence and irrational fluctuations of retributive temper in the successive Congresses that enacted particular criminal laws. The pressure on the draftsman to create intermediate retributive categories is particularly strong when, as the staff proposed to the Conımission, the maximun short-tern sentence for a misdenieanor (imposed for purely deterrent purposes) should

196. Id. § 3725(a)(2).

197. Id. $\$ 3725(\mathrm{~d})(2)(\mathrm{B})$.

198. Compare Senator Kennedy's proposal for a federal sentencing commission to promulgate guidelines for trial judges. S. 2699, 94th Cong., 1st Sess. (1975). This bill was co-sponsored by Senators McClellan and Hruska.

199. COMMISSION CODE § 3002 .

200. See Study Draft xxxii-xxxiii. 
be three or six months while the maximum for the lowest felony grade might be in the neighborhood of four years. In vain did we argue that intermediate maxima like.one year or two years were gratuitously severe from a deterrent point of view and would usually be inadequate from the point of view of incapacitation or rehabilitation. The Commission itself adopted a one-year maximum for misdemeanors, ${ }^{201}$ and S. 1 intercalated a low-grade felony carrying a three-year maximum. ${ }^{202}$

Short-term imprisonment precludes any rehabilitation program, and there is no basis for believing that there is a significant deterrence differential between thirty days, six months or one year. Accordingly, misdemeanor penalties should be sharply restricted except for "persistent misdemeanants." ${ }^{203}$ S. 1 departed notably from the Commission Code by authorizing imprisonment for "infractions.",204

\section{Wiretapping}

On two issues, wiretapping and entrapment, S. 1 was not significantly worse than existing law, ${ }^{205}$ but the positions taken, needlessly in the case of wiretapping, were calculated to arouse the sharpest opposition. Wiretapping falls into the category of procedure and evidence, which the Brown Commission did not undertake to revise. ${ }^{206}$ The Commission Code simply penalized illegal wiretapping without addressing the question of the conditions under which wiretapping should be legal. ${ }^{207} \mathrm{~S}$. 1, on the other hand, incorporated ("reaffirms," opponents said) provisions of existing law detested by the liberal community. In addition, the Subcommittee Report added expansive glosses relating to warrantless eavesdropping in "emergencies," 208 to eavesdropping on persons not named in the warrants but $\mathrm{m}$ volved in the same suspected criminality, ${ }^{209}$ and to the need for merely "substantial compliance" with federal requirements to validate wiretapping by state police. 210

201. Commission CODE $\$ 3201(1)(d)$. The Study Draft presented a choice of a one-year, six-month or three-month maximum for misdemeanors. STUDY DRAFT § 3204(a).

202. S. $1 \S 2301(b)(5)$. S. 1 also departed from the Commission Code by authorizing up to five days imprisonment for "infractions." Compare S. 1 \$2301(b)(9) with COMmission CODE § 3001(3).

203. See Commission CODE $\S 3003$ (defining a "persistent misdemeanant" as a person who is convicted three times within five years for Class A misdemeanors or more serious crimes).

204. Compare S. 1 \$2301(b)(9) with CoMmission CODE § 3001(3).

205. S. $1 \S 3101-3109$ substantially reenacted the arrangements for eavesdropping by fcderal and state officials, sometimes with and sometimes without a warrant, which were introduced into federal law by the Omnibus Crime Control and Safe Streets Act of 1968, 18 U.S.C. $\$ \$ 2510,2515-2519$ (1970).

206. See note 19 supra and accompanying text.

207. COMMiSSION CODE § 1561(2)(a).

208. 3 SUBCOMMITTEE REPORT $945-46$.

209. Id. at 943.

210. Id. at 942 . 
The original miscalculation regarding the desirable scope of reform legislation led also to the "reaffirmation" in S. 1 of other extremely controversial recent statutes. Thus section 3713 purported to render confessions admissible notwithstanding violation of the Miranda rules on interrogation of uncounseled suspects held in police custody; and section 3714 purported to render eyewitness testimony admissible regardless of improper pretrial police influence upon the witness to make a desired identification. That these sections were wholly or partially unconstitutional ${ }^{211}$ could only intensify the outrage felt by opponents of such needless "reaffirmation" of congressional assaults on the Supreme Court's interpretation of the Bill of Rights.

\section{E. Entrapment}

Under existing law, entrapment is handled as a substantive defense, that is, it raises a question regarding the defendant's criminal intent. ${ }^{212}$ The Brown Commission therefore could not finesse the issue by categorizing it as one falling outside the range of its proposed reform of substantive penal law. The basic question was whether the law should tolerate the conviction of defendants for committing crimes which they were induced to commit by improper pressure from police agents. Section 551 of S. 1, following existing law, permitted such convictions. The culprit might have acted "solely as a result of active inducement" by a law enforcement officer, but the prosecution would nevertheless succeed if the culprit had been "predisposed" to commit the offense. ${ }^{213}$ The Commission took the predisposition issue out of the analysis and concentrated instead on the propriety of the police behavior. The police would be free, under the Commission proposals, to set up an "opportunity to commit an offense," for example, to offer to buy narcotics from a suspected seller. They would be forbidden only to use "means likely to cause normally law-abiding persons to commit the offense," 214 but that prohibition would apply without regard to the character or predisposition of the target.

The Commission's position commends itself on the following grounds. First, it gives clear guidelines to the police as to what society will tolerate in

211. See Miranda v. Arizona, 384 U.S. 436 (1966) (requiring police to inform suspects in custody of their constitutional rights prior to interrogation); United States v. Wade, 388 U.S. 218 (1967) (accused has right to have counsel present at post-indictment line-up); Gilbert v. California, 388 U.S. 263 (1967) (testimony that witnesses had identified defendant at illegal line-up is inadmissible). But cf. United States v. Ash, 413 U.S. 300 (1973) (no right to counsel at post-indictment photographic display); Kirby v. Illinois, 406 U.S. 682 (1972) (no right to counsel at pre-indictment show-up).

212. See United States v. Russell, 411 U.S. 423 (1973); Sherman v. United States, 356 U.S. 369 (1958); Sorrells v. United States, 287 U.S. 435 (1932).

213. S. $1 \S 551$ (emphasis added).

214. COMMISSION CODE § 702(2). 
the way of police inducement. It does not say, as does S. 1: "You may go so far sometimes and much further at other times (if the suspect is 'predisposed')," at the risk that a jury will later find that the suspect was not sufficiently predisposed. Second, it avoids the perversion of criminal trials into inquisitions regarding the accused's predisposition as manifested by his alleged participation in prior offenses not involved in the present charge. It is inconsistent with the whole tradition of Anglo-American law to try a man for his character, or to make conviction or acquittal of two defendants, both of whom have engaged in the same conduct with the same criminal intent, dependent on their alleged criminal proclivities. Third, dealing with entrapment as a bar to prosecution on account of police impropriety rather than as an element of the defendant's guilt is consistent with the handling of other similar problems in criminal law, for example, the exclusion of coerced confessions and illegally obtained evidence, where the government is barred from exploiting its own lawlessness regardless of the defendant's guilt. Fourth, treating entrapment as a bar lightens the burden of proof for the prosecution, which will not then have to negate entrapment "beyond a reasonable doubt."

\section{F. Public Safety Orders; Riots}

The Commission sought to narrow the scope of the ancient "riot" offense, which permitted mass arrests without discriminating among leaders, followers and mere bystanders. ${ }^{215}$ At the same time the Commission wished to take realistic account of the difficulty police have under riot conditions in distinguishing between participants and bystanders, and of the need on occasion to require that even the rights of bystanders give way. For this purpose the Commission proposed that superior police officials, in controlling riots and promoting public safety, might issue reasonable orders to move, disperse, or refrain from specified activities in the immediate vicinity of the riot. Violations of such orders were to be "infractions" only, that is, noncriminal finable offenses like traffic violations. ${ }^{216}$ Under S. 1 , the public safety order could be given by any policeman or other public servant without authorization by higher authority, and violation of this minimal riot control measure could result in a five-day jail sentence. ${ }^{217}$

215. See id. \$§ 1801 et seq.

216. Id. § 1804. An additional desirable safeguard, proposed in STUDY DRAFT § 1804, would have excluded police orders directed to news reporters, television cameramen and the like, to discourage the not infrequent efforts of riot control forces to operate free of public surveillance. When the Study Draft was being considered by the Commission, I favored a broader explicit exclusion of elective and other officials who might be interested in first-hand observation of the riot and control measures. The conservative wing of the Brown Commission persuaded the Commission to drop these additional safeguards.

217. S. $1 \S 1862,2301(b)(9)$. 


\section{G. Miscellaneous}

This catalogue of repressive features of S. 1 may conclude with a reference to the significant alteration S. 1 made in the Brown Commission's statement of Purposes of the Code. ${ }^{218}$ In the first place, S. 1 dropped the Commission's declared purpose "to safeguard conduct that is without guilt from condemnation as criminal." 219 That declaration was the closest that either bill came to adopting the principle of "strict construction" of penal laws; both bills call for construction "in accordance with the fair import of their terms to effectuate the general purpose" of the Code. ${ }^{220}$ The more conventional canon of strict construction is a relic of the ages when the common law (i.e., judicial power to define crime) was sacrosanct and legislation was regarded as a suspect intrusion. In a modern setting, strict construction leads to absurd judicial results, to obstruction of clear legislative purpose and to extraordinary, self-defeating complexity of drafting as legislators seek to anticipate every potential "strict construction." Nevertheless, there is an important value to be preserved in having legislation drafted and interpreted with a sensitivity to the tendency of every generalized prohibition to imperil behavior that is neutral or even desirable. That was the teaching of the "purpose" which S. 1 deleted.

Second, S. 1 unmistakably emphasized retribution as the purpose to be given priority in the interpretation and administration of the Code. Where the Commission spoke of insuring public safety, 221 S. 1 spoke of "assur[ing] just punishment." 222 Some might think that these subtle shifts of emphasis have little practical import, especially in a context that lists all the usual (and inherently contradictory) goals of the criminal justice system: deterrence, rehabilitation, incapacitation and, in the Commission Code as well as in S. 1, "merited punishnent." But we are dealing here with the first attempt to articulate by federal legislation the complex goals of the criminal justice system. To list the purposes, however contradictory and however equivocal in aggregate effect, is to make sure that no consideration is overlooked-legislators, judges and the public are thereby educated, and counsel have a statutory text to invoke. But it is something of a disaster to go further, pushing the priority of a "just deserts" philosophy and deprecating the ancient wisdom that a penal law must not so zealously pursue the wicked as to endanger the innocent.

\section{FlatUlence ON THE LefT: The RHETORIC OF OPPOSITION}

The provocation from the Right was great. The response from the Left

218. COMMISSION CODE $§ 102$.

219. Id. \& 102(d).

220. S. 1 § 112(a); cf. Commission CODE $\S 102$, Comment.

221. COMMISSION CODE $\S 102(\mathrm{a})$.

222. S. $1 \S 101(\mathrm{~b})(1)$. 
was demagogic, deceptive and probably counterproductive in the struggle to promote liberty and justice. A mighty stench was generated to "STOP S. 1.",223 The campaign did not discriminate between good provisions of S. 1 and the very bad provisions, nor between the bad provisions introduced by S. 1 and the rest which merely retained existing law. On the contrary, the Left insisted that the bill was so infused with fascism as to be unamendable. Most disappointing was the failure of the Left to recognize that reform of the criminal law was itself a civil liberties project that should enlist their fervent support. Americans for Democratic Action, a leading left-of-center group, did see the point, and combined its strong opposition to $S .1$ with a powerful affirmative statement on the need for reform. ${ }^{224}$ The habituation of most other civil liberties groups to being against perceived encroachments on freedom prevented them in this instance from recognizing the affirmative civil rights need for criminal law reform. They failed to comprehend that positive legislation was essential in the field of criminal law as it was in the field dealt with in the Civil Rights Acts of 1964 and 1968. ${ }^{225}$ The Left nounted no campaign for criminal law reform. From the civil rights establishment came only an occasional, grudging, "We do not oppose revision of the Federal Criminal Code," combined with a blanket condemnation of S. 1 as "inherently unamendable.",226

223. The chief movers in the STOP S. 1 campaign were the American Civil Liberties Union, the National Committee Against Repressive Legislation and the National Lawyers Guild.

224. The ADA position was as follows:

Versions of the federal criminal code developed by the McClellan subcommittee of the Senate Judiciary Committee (S. 1) and the Department of Justice (S. 1400) are repressive and regressive.

ADA calls for the support of a new federal criminal code along the lines proposed by the National Commission on Reform of Federal Criminal Laws headed by former Governor Pat Brown of California. Specifically, we:

1. oppose capital punishment and life sentences without possibility of parole;

2 . oppose mandatory minimum sentences which preclude judicial adaptation of sentence to individual cases, and invade the function of parole boards;

3 . oppose the tendency to government censorship involved in regressive obscenity legislation and suggestions that executive classification of information should be backed by criminal sanctions;

4. oppose the abolition of the defense of insanity as envisioned in S. 1400;

5. oppose imprisonment for possession and use of marijuana;

6. oppose indiscriminate incorporation of state and local penal law (often antiquated and medievally harsh) for federal enclaves;

7. insist upon effective national control of the private possession of handguns;

8. insist upon legislative formulation of standards for parole and probation, with a presumption in favor of liberty unless the judge or parole board believes that the goals of punishment are better served by imprisonment;

9. favor more local responsibility through a declaration in the federal code against federalizing trivial local offenses, especially in areas like gambling, prostitution, petty frauds. The mere fact that the federal mails or a telephone call are peripherally involved should not lead to federal involvement;

10. favor systematized grading of "regulatory offenses"-i.e., violations of administrative rules involving no evil intent or substantial harm, and no manifest risk to the interests of others-and elimination of imprisonment as a sanction for a first offense of this type.

Americans for Democratic Action, 1974 ADA National Policy 107.

225. Civil Rights Act of 1964, 42 U.S.C. $\$ \S 2000$ a et seq. (1970); Civil Rights Act of 1968, 82

Stat. 73 (codified in scattered sections of $18,25,28$ and 42 U.S.C.).

226. Countryman \& Emerson, What Constitutional Authorities Think of the Bill!, in Nation- 
Alexander Hamilton, writing in The Federalist about the opponents of the constitutional proposal for an independent judiciary, referred to "the rage for objection which disorders their imaginations and judgments." ${ }^{227} \mathrm{He}$ might have said the same of the intemperate rhetoric of the Left when it excoriated S. 1 as a plot by Nixon and his Watergate gang to enslave the nation, to provide defenses for themselves in pending prosecutions, and to facilitate future usurpations by the Executive Branch. The fact that John Dean, who had participated in the White House "cover-up," had several years before been a member of the Brown Commission staff was put forward by some as an explanation for the Commission Code provisions on mistake of law and performance of public duty which arguably would exculpate the Watergate offenders. This argument ignored the fact that Dean had nothing to do with the drafting of these sections, which indeed merely followed Model Penal Code recommendations of the American Law Institute published a decade before the plots in the Nixon White House. If one wished to make a plausible connection between Dean's work at the Brown Commission and the debacle at the White House, it might better have been this: Dean did work on portions of the Code having to do with perjury and obstruction of justice; that work could well have sensitized him to the danger of criminal prosecution for the cover-up, and so figured in his decision, first, to warn his Chief and then to "blow the whistle," that is, disengage himself from the conspiracy and cooperate with the prosecutors. ${ }^{228}$

al Committee Against Repressive Legislation, Dangerous S.B.1 (brochure published by opponents of S. 1). Professors Countryman and Emerson went on to declare that "'t $t]$ he objective of the draftsmen was to incorporate in the criminal code every restriction upon individual liberties, every method and device, that the Nixon Administration thought necessary or useful in pursuit of its fearful and corrupt policies." Id. This astonishing statement disregards not only the numerous consensus libertarian reforms listed earlier, see notes 49-116 supra and accompanying text, but also such aspects of S. 1 as its harsh dealing with perjury and obstruction of justice, see notes 164-75 supra and accompanying text, two offenses at the heart of the White House conspiracy, and the several advances made by $\mathrm{S} .1$ in conventional civil liberties areas. See notes $93-96$ supra and accompanying text.

227. The Federalist No. 78, at 483 (H. Lodge ed. 1888) (A. Hamilton).

228. An interesting sidelight on Dean and the canard that he was a White House tool for distorting the reform of the Code is provided by his work on the capital punishment controversy. Dean's employment at the Brown Commission had been sponsored by the conservative members, and like them he favored capital punishment. When it came time to address this issue, $I$ decided to restrict the staff submission to a survey of preceding research and literature because it was clear that any advocacy by me would be attributed to my known abolitionist convictions and would persuade no one on the other side. I asked Dean, a known proponent of capital punishment, to do the survey. After spending six weeks on the project he informed me that, as a result of his reading, he had changed his mind. See 2 COMmISSION WORKING PAPERS 1347. His conservative sponsors were quite unhappy. Later, when Watergate broke, I found myself being interviewed by press and broadcast media about my former employee. Some of the interviewers insisted on interpreting these events as showing that Dean was "unprincipled"! Some might prefer the interpretation that Dean was intelligent, open-minded and responsive to evidence. 


\section{A. Mistake of Law; Superior Orders; the "Ehrlichman.Defense"}

The main targets of the "STOP S. 1" campaign, apart from the censorship issues discussed above ${ }^{229}$ obviously calling for strenuous resistance, were the defenses which supposedly would exculpate perpetrators of official crimes of the Watergate type, ${ }^{230}$ and provisions that would supposedly authorize suppression of protests such as the anti-Vietnam War demonstrations. ${ }^{231}$

The controversy over the so-called Ehrlichman defense ${ }^{232}$ illustrates the worst features of the "STOP S. 1" campaign. As will be shown below, the S. 1 proposal was misinterpreted. Even as misinterpreted, it erred, if at all, on the side of civil liberty, not against it. ${ }^{233}$ Moreover, even if the provision could indeed be construed to exculpate the architects of the Watergate cover-up, that loophole could be closed by a single clarifying amendment. Instead, the Left chose to hold the entire penal reform proposal hostage to a dubious interpretation of a peripheral provision. Finally, it may be noted that the District of Columbia Court of Appeals, speaking largely through Chief Judge Bazelon-whose civil libertarian badge is as shiny as anyone's-has recently vindicated the policy position challenged by ACLU and NCARL. Precisely in the cases of Ehrlichman and the "footsoldiers" who obstructed justice or burglarized on orders from the White House, the court sustained convictions against high officials despite their incredible claims of good faith reliance on superiors, ${ }^{234}$ but drew the line against treating as criminals underlings who act in good faith reasonably believing that they were executing official duties lawfully defined for them by seemingly responsible superiors. ${ }^{235}$

The S. 1 sections in question are section 541 (exercise of public authority), section 521 (mistake of law or fact) and section 552 (official

229. See text accompanying notes 139-49 supra.

230. From the cover of ACLU's pamphlet, STOP S-1: "Did you think the President's men could claim they were just following orders? S. 1 could let them out of jail." ACLU, supra note 148 , at 1 .

231. From the cover of the ACLU pamphlet, STOP S-1: "Did you Protest the Vietnam War? S. 1 could put you in jail." Id.

232. See United States v. Ehrlichman, 546 F.2d 910 (D.C. Cir. 1976), cert. denied, 45 U.S.L.W. 3764 (U.S. May 23, 1977). Former Presidential advisor John Ehrlichman asserted that his order to break into the offices of a psychiatrist did not constitute taking part in a conspiracy to violate the victim's civil rights because he was acting under an inexplicit mandate from the President.

committee or the White House, as paranoid elements of the Left would have had it, but with the liberal drafters of the Model Penal Code and the Brown Commission Code.

234. United States v. Ehrlichman, 546 F.2d 910 (D.C. Cir. 1976), cert. denied, 45 U.S.L.W. 3764 (U.S. May 23, 1977).

235. United States v. Barker, 546 F.2d 940 (D.C. Cir. 1976). The "footsoldiers" also won a $\$ 200,000$ settlement from the trustees of the Committee to Reelect the President in a lawsuit based on their having been duped into committing illegal acts by false representations that the government had sanctioned these acts. N.Y. Times, Feb. 23, 1977, at 1, col. 1. 
misstatement of law). The corresponding sections of the Commission Code are section 602 (execution of public duty), section 304 (ignorance or mistake negativing culpability) and section 609 (mistake of law). In general, these sections provide that activities which would be criminal for laymen are not criminal for officials lawfully carrying out their public duties. The public executioner is not a murderer. The policeman taking a lawfully arrested suspect to the stationhouse is not a kidnapper. These propositions are not controverted by anyone. Indeed, they are truisms or tautologies: lawful action is not crime. Nevertheless, a code that purports to be comprehensive is incomplete if it contains unqualified condemnations of homicide and abduction without explicitly recognizing that there may be occasions when such behavior is justified. Controversy arises only in the case of a person who acts on mistaken belief that he is so justified. Under what circumstances should that belief be accepted as an excuse? In modern law, excuse for reasonable mistake is quite broadly accepted, as in the case of mistakes of fact in the exercise of the privileges of self-defense, defense of habitation or prevention of violent felonies. The excuse is an application of the general civil liberties principle that culpability ought to be proved before the state may be allowed to punish.

Two refinements of the general rule of exculpation for reasonable mistake must be considered in the present context. These relate to mistakes of law and to actions taken while carrying out orders given by a superior. Mistaken belief as to the coverage of the penal law itself is not an accepted excuse unless the reasonableness of the mistake rests on some objective foundation such as authoritative judicial interpretation or official pronouncement by responsible law enforcement agencies. ${ }^{236}$ This limitation of excuse is seen as necessary to prevent factitious defenses, perhaps based on the advice of corrupt or ignorant lawyers. ${ }^{237}$ On the other hand, mistake of law will sometimes excuse even if the belief is unreasonable, where the special kind of culpability required by the definition of an offense is negated by the mistake. ${ }^{238}$

236. S. $1 \S 552$; COMMISSION CODE $\S 609$.

237. But see Long v. State, 44 Del. 262,65 A.2d 489 (1949) (defense in a bigamy prosecution that accused reasonably believed, relying on counsel's opinion, that a foreign divorce from his first wife was legally valid).

238. See S. 1 \$ 521; Commission CODE § 304. See, e.g., Raley v. Ohio, 360 U.S. 423 (1959) (no contempt of court in defying order to testify in reliance on honest belief, based on attorney's advice, that respondent enjoyed the constitutional privilege against selfincrimination); Screws v. United States, 325 U.S. 91 (1945) (no deprivation of federally secured civil rights without specific awareness that behavior is "that which the statute forbids"); People v. Shaunding, 268 Mich. 218, 255 N.W. 770 (1934) (no larceny in the taking of goods of which one believes himself the owner, though he is mistaken as to controlling law); People v. Weiss, 276 N.Y. 384, 12 N.E.2d 514 (1938) (no kidnapping if one supposes himself to be acting in authorized collaboration with law enforcement agencies). For excellent surveys of the precedents on mistake of law, see 1 COMmISSION WORKING PAPERS 135-41; 2 SUBCOMMITTEe REPORT 154-58. 
The "superior orders" defense supplements the mistake of law defense. It functions as a kind of presumption in certain hierarchical organizations (for example, the army) that a person authorized by society to issue drastically enforceable commands knows what he is doing, knows whether or not his command is lawful, and is entitled to obedience. Conversely, the subordinate, upon whom society has laid a powerful duty of obedience, is not ordinarily deemed culpable if he allows his duty to obey to outweigh doubts as to the legality of the command; he is liabile only if he knows the command is unlawful. ${ }^{239}$ The defense is not couched in terms of mistake of law, reasonable or unreasonable, because in the typical situation in which it is intended to operate, no legal opinion is being proffered or received. Accordingly, the privilege to obey need not be circumscribed, like the mistake of law defense, by requirements that the command emanate from a high and responsible source or be in writing.

Against this background we may appraise the opposing positions in the controversy over the "Ehrlichnian defense." What emerges is that the Left took a strikingly anti-civil liberties position. Trapped by its own volleys of rhetoric against S. 1 as a McClellan-Nixon conspiracy, and responding only to yesterday's headlines rather than to the lessons of history, it rushed into a "law-and-order" position to the right of Senator McClellan on mistake of law: subordinate public servants and ordinary citizens acting at the request of even high officials were to be convicted of crimes without regard to their good faith belief that they were following society's lawful mandate like model or even heroic citizens. The paradoxical anti-civil libertarian thrust of this reaction is strikingly demonstrated by the situations presented in Raley v. Ohio ${ }^{240}$ and Cox v. Louisiana. ${ }^{241}$ In Raley, the Supreme Court unanimously reversed the contempt convictions of witnesses who had refused to testify before a state investigating committee on grounds of selfincrimination, after the committee had mistakenly advised the witnesses that the privilege was available to them. The Court found this to be "an indefensible sort of entrapment." 242 In Cox, convictions for attempting to obstruct justice by demonstrating "near" a courthouse were reversed because of evidence that the chief of police on the scene had opined that parading across the street from the courthouse was not "near," although his unwritten "official" interpretation was subsequently held erroneous. ${ }^{243}$ The

239. See Model Penal Code $\S 2.10$ (Proposed Official Draft 1962) (military orders); $c f$. COMMISsion CODE $\S 602(2)$ (person who responds to public servant's directive to use force in assisting him is exculpated unless the action directed is "plainly unlawful"). For a discussion of the desirability of encouraging citizens to respond to apparently official calls for aid, see United States v. Barker, 546 F.2d 940 (D.C. Cir. 1976).

240. 360 U.S. 423 (1959).

241. 379 U.S. 559 (1965).

242. 360 U.S. at $437-39,443$.

243. 379 U.S. at $568-72$. 
position advocated by the Left would unavoidably have led to these convictions being upheld.

The civil liberties implications of a generous mistake of law/superior orders defense are even broader than indicated by the foregoing illustrations of their relation to the right to claim constitutional privileges or to exercise freedom of speech and assembly. There are hundreds of thousands of public servants whose duties involve arrest and search behavior ordinarily prohibited by law: customs officers, revenue agents, building guards, policemen, firemen, investigating officials and so on. The line between what is lawful for them to do and what is unlawful is notoriously vague, yet they are under pressure zealously to do all that is lawful in carrying out their responsibilities. Excesses of zeal must be corrected, and in cases of gross and willful abuse of official authority, they must be prosecuted as crimes. But surely in a civilized society the correction of nonculpable transgressions of vaguely defined authority should not be accomplished by criminal prosecution where the servant acted in good faith obedience to seemingly lawful directions of high authorities. It is the errant high authorities who are shown to be at fault, and such correction as is required for too-obedient subordinates should take the form of better training and of civil disciplinary measures such as suspension or discharge from employment. The Supreme Court was plainly right in suggesting in Raley that it would amount to entrapment for society to train and arm men for law enforcement duties, place them in quasi-military subordination to superiors, and then prosecute them for conforming to plausible commands. Even if the mistake of law defense were narrowly defined for ordinary applications, it would have to be broadened for people placed in such circumstances. The ordinary citizen acts on his own initiative in complying or not conplying with the law. He is not placed in a crossfire between official demand that he act aggressively and official threat of punishment if the aggressive act, though conforming to a plausible particularization of society's demand through superior orders, is subsequently held to be unlawful.

There are ironies in the position taken by the Left on the Ehrlichman defense apart from the spectacle of civil libertarians adopting a harsh law-and-order stance against selected targets. The targets were vulnerable without distorting the law of justification, and the net result of a successful campaign to discredit defenses has been to reinstate aspects of present law that should be detestable to knowledgeable civil libertarians. Ehrlichman could not have gotten off even if the law had left open the possibility of a good faith defense under some circumstances. All that was needed to convict him were instructions to the jury that the good faith defense did not extend to "unreasonable" reliance on others' legal opinions (especially when the actor was a lawyer or legally sophisticated), that it did not extend 
to orders given outside the military context which did not purport to be legal opinions from an impartial source, and that it most assuredly did not extend to orders or legal opinions emanating from a fellow conspirator. ${ }^{244}$ In correspondence with the American Civil Liberties Union, I proffered a simple draft which would have explicitly required such instructions. The suggestions proved unacceptable, however, to groups already committed to the proposition that $\mathrm{S}$. 1 was not amendable.

But of course S. 1 was amendable, and the Left eventually acknowledged that by sponsoring H.R. $10850,{ }^{245}$ its own amended version of S. 1 . In that bill, section 501 provided that the defenses specified "are not exclusive ... Additional bars and defenses may be developed by the Courts of the U.S. in the light of reason and experience." 246 This departure from the Commission Code is both vague and counterintuitive. Quite plainly, for example, the public duty defense just discussed has not been "abolished"' as the draftsmen seem to have intended. The courts are left free to adopt whatever rule they like. The open-ended invitation to judges to add to the listed defenses is a civil liberties monster. It was earlier urged on the Brown Commission by the Right in order to retain all sorts of bad thingsfor example, the right of police to kill in suppressing riots and the right of a householder to shoot to kill a supposedly burglarious intruder whether or not he is perceived as a threat to life (as where the burglar is shot leaving the house). To leave the judges free to define defenses is virtually to abandon the effort to define crimes, since an offense is defined by the combination of what it prohibits and what is declared to be justified.

\section{B. Repression of Political Dissent}

The Left's position on the potential of S. 1 for repression of political dissent was based on a number of provisions that reenacted, usually with some amelioration, existing law. One cannot disagree with criticism directed at the overreach of existing espionage, sedition, sabotage, and riot law; the Brown Commission proposed substantial cutbacks in these areas. But it is quixotic to reject a multi-faceted reform code because one has not

244. The Criminal Justice Section of the American Bar Association supported the position of the Judiciary Subcommittee that the Ehrlichman defense was adequately precluded by requiring the exculpating official opinion to be "public." AMERICAN BAR Association, CrimINAL JUSTICE SECTION, supra note 192, at 11. The proposal was inadequate in two respects. It did not afford a defense based on superior orders rather than legal opinions, and it did not cover the situation of orders or legal opinions necessarily given in private, as in the Barker case, but reasonably relied on by subordinates. This portion of the Criminal Justice Section's report was rejected by the House of Delegates on June 4, 1975. AMERICAN BAR AsSOCIATION, SUMmaRY OF ACTION TAKEN BY THE House OF DELEgATES 34 (1975).

245. H.R. 10850, 94th Cong., 1st Sess. (1975). The bill was subsequently revised and reintroduced as H.R. 12504, 94th Cong., 2d Sess. (1976).

246. H.R. 10850, $\S 501,94$ th Cong., 1st Sess. (1975). S. 1 contained a similar provision, S. $1 \S$ 501 , without the express invitation to the courts to develop additional defenses. 
achieved all one's desires with respect to these rarely invoked laws.

The Left's objection was primarily directed against section 1302 of S. 1 , which made it a misdemeanor to "intentionally obstruct, impair, or pervert a government function by means of physical interference or obstacle." 247 The ACLU objected that this statute

could be misused against lawful and peaceful demonstrations. Virtually every mass demonstration would, at one moment or another, fall within [the] prohibition . . . . [I]t would be up to the prosecutor to determine whether a large demonstration on federal grounds or near federal buildings was or was not "physically interfering" with some government function. Even an influx of cars carrying demonstrators to the chosen site might constitute the proscribed felony. Since mass arrests on the basis of group behavior are constitutionally forbidden by the particularity requirements of the Fourth Amendment, the statutes would lend themselves to selective abuse by law enforcement officials. ${ }^{248}$

A response to these criticisms must begin by noting that section 1302 of S. 1 derived from section 2421 of the Model Penal Code and section 1301 of the Brown Commission Code; ${ }^{249}$ thus it was not a product of a Nixonite conspiracy. The section was designed to replace a variety of existing laws dealing with obstructions of particular governmental operations such as "the due administration of justice," 250 the activities of law enforcement and correctional officers, ${ }^{251}$ United States marshals and other officials serving or executing judicial process, ${ }^{252}$ the mails, ${ }^{253}$ grain inspection ${ }^{254}$ and military recruiting. ${ }^{255}$ The list is not exhaustive. Moreover, existing statutes are not always restricted to physical obstruction; they are not always limited to intentional obstruction; the penalties they prescribe vary irrationally; and they rarely articulate the defense found in $S .1$ that the governmental activities obstructed are unlawful. ${ }^{256}$

It is hard to believe that the Left knowingly sought to legitimate obstruction of the mails or grain inspection, of judicial decrees against racial segregation of public schools or of judicial decrees protecting Blacks' right

247. S. 1 \$1302(a).

248. ACLU, supra note 148 , at 8.

249. A significant difference, however, is that $S .1$ penalized physical obstruction even of unlawful government activity if the official was acting "in good faith." See S. 1 \$ 1302(b).

250. 18 U.S.C. $\$ 1503$ (1970) ("endeavors to influence, obstruct, or impede . . . corruptly or by threats of force").

251. Id. $\$ \$ 1502$ (law enforcement officers), 2231-33 (correctional officers).

252. Id. $\$ \S 111,1501$.

253. Id. § 1701 .

254. 7 U.S.C. $\S 87(b)(8)(1970)$.

255. 18 U.S.C. \& 2388 (1970).

256. See 2 SUbCommittee Report 302. 
to vote. It is hard to take seriously the notion that because prosecutors might abuse laws against obstruction of government, we should have no such laws; that we should, for example, repeal traffic laws or the trespass laws, which also can be and have been abusively employed against peaceful demonstrators. Unfortunately the unabusable law has not yet been invented, and we must still rely on the first and fourteenth amendments to guard against perverted applications of otherwise useful legislation. The real beneficiaries of the repeal of laws against the obstruction of government will be those who oppose federal marshals enforcing the civil rights laws, those who impede the pursuit of drug smugglers or terrorists, and those who would sabotage the fire-fighting arrangements of a federal forest ranger.

\section{Disorderly Conduct and Assimilated Offenses}

The Brown Commission, drawing on the Model Penal Code, drafted a narrow and precise definition of disorderly conduct and made it punishable by fine only. ${ }^{257}$ Rigid ideology and legal ineptitude led the Left to reject that solution. Responding only to the notorious potential for abuse in vaguely defined misdemeanors characterized as "disorderly conduct" or "vagrancy," the Left proposed a section which failed to cover obvious public disorders such as exploding stink bombs in public places, intentionally harassing passersby in public places by persistent obscenities and intentionally rendering public highways, subway platforms or train stations unusable by physical obstruction. ${ }^{258}$ The Left envisioned a penal code without any provision against "indecent exposure." 259 These omissions were all the more imprudent because the Left's proposals also, quite inexplicably, omitted any provision for assimilating for federal enclaves minor offenses defined in the law of adjoining states. ${ }^{260}$ As a result, federal forts, reservations and the like would be converted into havens for behavior legitimately proscribed by the surrounding communities. Moreover, since no federal penal code will ever be enacted without an assimilated crimes provision, the Left's rejection of decently circumscribed federal definitions of disorderly conduct would mean that state law definitions-often harsh and arbitrary-would replace federal law.

257. COMMISSION CODE $\S 1861$. The section does authorize up to thirty days imprisonment for soliciting sexual contact while loitering in a public place. Id. $\$ \S 1861(1)(\mathrm{f}), 3201(1)(\mathrm{e})$.

258. H.R. 10850, $\S 1861,94$ th Cong., 1st Sess. (1975):

A person is guilty of [disorderly conduct] if, with intent to alarm, harass, or annoy another person or in reckless disregard of the fact that another person is thereby alarmed, harassed, or annoyed, he engages in violent, tumultuous, or threatening conduct.

259. There was no analog in H.R. 10850 to Commission Code $\S 1852$, which limits the misdemeanor to situations where the indecent exposure would alarm or seriously offend the unwilling onlooker.

260. See note 66 supra and accompanying text. 


\section{Anti-Libertarian Proposals from the Left}

The tunnel vision that sees legislation only from the point of view of potential abuse or of yesterday's Watergate headlines led the Left to make proposals of extraordinary severity and repressiveness. For example, the Left proposed to penalize disobedience of a court order by a maximum of two years imprisonment. ${ }^{261}$ Only liberals with a short memory could thus undertake to subvert the Brown Commission's effort to restrict the tyranny of punishment for judicial contempt. ${ }^{262}$ Obviously the draftsman was reacting angrily to recent disobedience of court orders in desegregation cases. He was not thinking of disobedience of injunctions against strikes or picketing.

Similarly, the proposal to make it a felony for officials to "deceive the public"'263 is an astounding measure to be born among civil libertarians. Is it really desired that, notwithstanding the first amendment, criminal courts become the forum for testing the validity of public pronouncements about defense needs and plans, crop prospects, food and drug research, inflation, unemployment and housing? Who but a General Stillwell or a Daniel Ellsberg would be targets of such prosecutions? Are we so naive as to believe that the FBI must always announce accurately its suspects and intentions in a proposed drive on organized crime or that public announcements on international relations accurately reflect sympathies? Should civil libertarians leap to espouse criminal law solutions for problems much better handled by disciplining or dismissing faithless public employees, or just by public discussion?

\section{E. Compromise Rejected: Snatching Defeat from the Jaws of Victory}

By August, 1975, under the influence of liberal Senators Hart of Michigan, Kennedy of Massachusetts and Abourezk of South Dakota, a considerable anielioration of S. 1 had been accepted by the Right. ${ }^{264}$ In the spring of 1976 a final push by the same group of senators was remarkably successful in gaining new concessions sufficient to render S. 1 a proper vehicle for reform of the federal criminal code. The "STOP S.

261. H.R. 10850, $\S 1335,2301(a)(4)$.

262. The Commission Code limits imprisonment for contempt to six months. Commission CODE $§ 1341(2)$.

263. H.R. 10850, § 1346(a):

A non-elected public servant is guilty of an offense if he, with intent to deceive the public, makes a false, fictitious or fraudulent and material oral or written statement or representation about any matter within the jurisdiction ... of a department or agency of the United States.

264. See S. 1, 94th Cong., 1st Sess. (1975), which was reported to the full Committee on October 21, 1975. The bill was reprinted under date of April 1, 1976, and was accompanied by a * draft Committee report bearing the same date. See StafF of SENATE COMM. ON THE JudiciarY, supra note 116. 
1" campaign had been so effective that it had become apparent to the Right that reform would founder unless they compromised. Senator Hruska was to retire at the end of the Ninety-fourth Congress, and Senator McClellan had only two more years to the end of his last term. Both men viewed reform of the penal code as intrinsically important and as a fitting crown to their legislative careers. Pragmatic politicians, they were prepared to give up on most of the provisions that stood in the way of the Senate passing a reform bill. In addition, the Administration, through Attorney General Levi, issued a statement welcoming "accommodation." 265 Concessions from the Right ${ }^{266}$ included the following:

(1) There was to be a "new bill"; the reform bill would no longer carry the hated designation S. 1. Although this looks like a pure formality, it was not. It was a politically significant symoblic act; the Right was striking its flag, and the Left would be given its triumph without having to eat its hard words about the unamendability of the McClellan bill.

(2) The "official secrets" provisions would be dropped. ${ }^{267}$

(3) Sentencing maxima would be substantially lowered. ${ }^{268}$

(4) Provision for capital punishment would be dropped, ${ }^{269}$ deferring the issue to separate disposition after the Supreme Court's decision of pending cases challenging the constitutionality of that penalty and the procedures for imposing it. ${ }^{270}$

(5) Section 3714 relating to admissibility at trial of eyewitness identification notwithstanding improper pre-identification influences by the police would be dropped. The analogous section 3713 relating to admissibility of "voluntary" confessions by uncounseled suspects in police custody would be qualified by an introductory clause: "unless otherwise required by the Constitution." 271

(6) Substantial limitations were accepted on existing legislation (on the books since the jittery days of 1917) dealing with wartime sabotage. ${ }^{272}$

(7) Possession of "small amounts" (under ten grams) of marijuana

265. Department of Justice, Press Release (April 6, 1976).

266. See Memorandum from Senators McClellan and Hruska to Senators Hart, Kennedy and Abourezk (March 25, 1976). This memorandum was written in response to a compromise proposal circulated by Senators Hart, Kennedy and Abourezk on March 8, 1976, which was itself a response to a memorandum from Senators Mansfield and Scott to Senators McClellan, Hruska, Hart and Kennedy dated February 9, 1976.

267. Id. at 3-4. See notes 139-49 supra and accompanying text.

268. Memorandum, supra note 266 , at 5 . See notes $160-76$ supra and accompanying text.

269. Memorandum, supra note 266 , at 5 ; see $\mathrm{S}$. 1 \$\$ 2401-2403.

270. The Supreme Court's decision in Gregg v. Georgia, 428 U.S. 153 (1976), would seem to sustain the constitutionality of the S. 1 proposals on capital punishment.

271. Memorandum, supra note 266 , at 6.

272. Id. at 3; see S. 1 \$ 1101, 1112, 1114. 
would be decriminalized. ${ }^{273}$

(8) The constitutional remnant, if any, of the Smith Act, ${ }^{274}$ directed against advocacy of violent overthrow of the government, was abandoned; there would be no "reaffirmation" of this dubious bit of existing law. ${ }^{275}$ This concession was all the more remarkable in that it went beyond the Brown Commission, which, out of political prudence, had contented itself with erecting safeguards against application of the Smith Act in contravention of the first amendment. ${ }^{276}$

(9) Defenses, other than the noncontroversial mistake of fact defense, would be dropped from the bill, leaving them to judicial development on a case-by-case basis. ${ }^{277}$ For reasons previously stated, ${ }^{278}$ this was a blow to the integrity of the Code, but it represented substantial concession from the Right. It meant, for example, abandoning the proposed repeal of the insanity defense ${ }^{279}$ and the attempt to codify the law on entrapment. 280

On the last two points, insanity and entrapment, the Left could hardly congratulate itself since the judge-made law to which the issues would be remitted was no more favorable to their views than the proposed statutory text. Down the legislative drain with these proposals went other less controversial justification provisions such as self-defense ${ }^{281}$ and defense of property. ${ }^{282}$ In these bypassed areas lurked such long-standing, nasty problems as whether or not an attacked person must make a safe retreat rather than kill his assailant, whether taking life is ever justifiable in defense of property, and whether policemen may, when it seems necessary, kill to effect arrests or prevent escapes. Regrettably, the Left, ${ }^{283}$ the Right, ${ }^{284}$ the American Bar Association ${ }^{285}$ and the Special Committee of the Judicial Conference of the United States on the Administration of the Criminal $\mathrm{Law}^{286}$ all agreed that most of these issues were inappropriate for legislative resolution.

273. Memorandum, supra note 266 , at 4 ; see S. 1 \& 1813(c)(2), making possession of marijuana a misdemeanor punishable by up to thirty days imprisonment. S. 1 \& 2301(b)(8).

274. 18 U.S.C. $\$ 2385$ (1970).

275. Memorandum, supra note 266, at 2.

276. See Commission CODE § 1103, Comment.

277. Memorandum, supra note 266, at 2.

278. See text accompanying text note 246 supra.

279. See notes 150-56 supra and accompanying text.

280. See notes 212-14 supra and accompanying text.

281. S. $1 \S 542$.

282. Id. $\S 543$.

283. See H.R. 10850, § 501. See note 246 supra and accompanying text.

284. See S. 1 \$.501 ("defenses to prosecution set forth in this chapter are not exclusive").

285. American Bar Association. Criminal Justice Section, supra note 192, at 6 ("No attempt should be made . . . to set forth . . . all defenses").

286. Committee on the Administration of the Criminal LaW, Judicial Conference of the United States, Report of ProceEdings 7 (Feb. 25, 1976). 
Rejected by Senators McClellan and Hruska were the following: (1) total repeal of the federal obscenity laws; (2) abandonment of the interstate commerce jurisdiction over riots; and (3) deletion of mandatory prison sentences for hard drug traffickers. ${ }^{287}$ On the issue of wiretapping, where most of the Left was demanding outright repeal, the liberal senators made politically more realistic demands for restricting the practice with regard to offenses covered, warrantless eavesdropping in "emergencies," "national security" taps and the like. The conservative senators did not refuse to negotiate on these proposals.

But for the Left there was no need to await the outcome of such negotiations. An ACLU press release on April 8, 1976, declared: "The 'hard-line' attitude of the two leading sponsors of this legislation lends little hope that S. 1 can be successfully overhauled during this session of Congress. The ACLU must therefore reaffirm its commitment to oppose Senate Bill 1 in its present form. "288 That statement was relatively mild. It implicitly recognized the amendability of S. 1 by expressing opposition to the bill only "in its present form." The ACLU's then-Washington Executive Director, Charles Morgan, had previously gone much further in an article in the Washington Star, denouncing the actions in the Senate as "A "Compromise' That Lynches the Constitution." 289 He took the position that no civil liberties issue could be deferred, and that all reform must await congressional agreement with the whole program of the ACLU, including repeal of wiretapping and obscenity laws, revision of existing espionage law and repeal of the law penalizing knowing misrepresentation by witnesses in governmental matters. ${ }^{290}$ No better formula could be devised for indefinitely postponing penal reform. Such brave progressive words meant, in the real world of legislation, a reactionary refusal to move forward. As for less responsible journals and journalists, the prospect of compromise had them foaming at the mouth. The Los Angeles Vanguard of June 4, 1976 headlined a five-column article entitled "Fascist Bill Creeps Thru Senate."291 The article characterized the bill, including pending changes, as "One Giant Goosestep for Mankind!," "the most evil legacy of the Nixon administration, Watergate taken to its most extreme law 'n order conclusion," and

287. Memorandum, supra note 266, at 4-5. See Hart/Kennedy/Abourezk Proposal, supra note 266. Federal jurisdiction over riots had already been somewhat curtailed by S. $1 \S \S$ 1831-1833, and a further curtailment was accepted by Senators McClellan and Hruska who agreed to delete "obstruction of a federal function" as a basis for federal jurisdiction. Memorandum, supra note 266 , at 4.

288. ACLU Press Release, April 8, 1976, at 1.

289. Morgan, $A$ "Compromise" That Lynches the Constitution, Washington Star, Feb. 29, 1976, at E-1, col. 1 .

290. Id.

291. Baker, Fascist Bill Creeps Thru Senate, Los Angeles Vanguard, June 4, 1976, at 3, col. 1. 
"blueprint for fascism." The role of the "so-called liberals" (Senators Kennedy, Hart and Abourezk) was described as driving NCARL officials "purple with rage."

Nevertheless, compromise remains very much alive. It now appears that the recently introduced McClellan-Kennedy bill, no longer designated S. 1 , will be the vehicle of reform in the Ninety-fifth Congress. ${ }^{292}$

\section{THE MEDIA}

With a few honorable exceptions, ${ }^{293}$ journalists and broadcasters defaulted on their obligation to educate the public on the issues of penal reform. The behavior of the Wall Street Journal, ordinarily a sophisticated paper, is illustrative. Responding to a letter from Senators McClellan and Hruska, ${ }^{294}$ the Journal published an editorial which focused on the official secrets issue, ${ }^{295}$ the length of the bill ("every Senator and Representative will [not] read all 753 pages"), ${ }^{296}$ and the desirability of "codification" as distinguished from reform (the bill "should not go beyond existing law"). ${ }^{297}$

The official secrets issue was indeed important, but to give it overwhelming prominence, as did most of the press, was also an act of censorship denying the public, at critical stages of the legislative process, intelligence regarding all the other important proposals in the legislation. ${ }^{298}$

292. See S. 1437, 95th Cong., 1st Sess. (1977).

293. See, e.g., Conley, The Growing Fight over Senate Bill 1, Memphis Com. Appeal, Jan. 11, 1976, §6, at 1, col. 1; McKenzie, New Criminal Code, Washington Post, Sept. 29, 1975, at 1. col. 6; Ungar, Reports and Comment: Law and Order Revisited, 238 ATLANTIC MONTHLY 12 (1976). I obviously have not made a comprehensive survey on this subject; but colleagues, former students and friends involved in the reform enterprise clipped the press for me, and called my attention to broadcasts. I am satisfied that the conclusion in the text is valid at least for the northeastern United States.

294. Letters to the Editor: Criminal Justice, Wall St. J., Aug. 22, 1975, at 8, col. 6.

295. Review and Outlook: Senate 1, Wall St. J., Aug. 22, 1975, at 8, col. 1.

296. Id. The Journal appears to have adopted page count as its paramount criterion in evaluating legislation. A lead editorial called upon President Ford to veto the Tax Reform Act of 1976 on the ground that it was 1500 pages long. The President was invited to promote his campaign for reelection "by having his advisers draw up a tax bill on one type-written page." Review and Outlook: Veto the Tax Bill, Wall St. J., Sept. 14, 1976, at 26, col. 1.

297. Review and Outlook: Senate 1, Wall St. J., Aug. 22, 1975, at 8, col. 1 (statement from the Montreal meeting of the American Bar Association House of Delegates).

298. It should be stated that the New York Times, as well as many other papers, gave comprehensive news coverage to the initial submission of the Brown Commission Report and to the introduction of S. 1. But these early summaries, written before battle lines had been drawn, could not supply the need later for reasonably comprehensive analysis of the fighting issues. The New York Times at one point commissioned an article to survey the reform project, but found it too complicated for the Times readership. It was eventually published in Gillers, Blueprint for Tyranny: Congress Overhauls the Laws, 222 NATION 172 (1976). The New York Times did run a short piece by me in the Sunday Week in Review Section. The editors, however, made a significant change. Where I had given first place to the sentencing reforms, to avoid the by-then-hackneyed priority which the newspapers had been giving to the newspaper- 
The proposition that comprehensive penal reform should be rejected because the bill was too long and would not be read by every legislator was, of course, ridiculous. The Journal was doing nothing less than mis-educating its readers regarding the democratic legislative process. If no bill could be enacted unless every legislator had read every page, legislation would come to a halt. Responsible legislators make up their minds on the basis of staff condensations and salient issues exposed by hearings, lobbying and public discussion. The President of the United States, who must concur in or veto every enactment of Congress, would find it impossible to exercise this legislative discretion if he were required to read (and think about?) every word in the tens of thousands of pages submitted to him every year. Tax bills of greater length than the criminal code reform bills are enacted regularly. ${ }^{299}$ In any event, two-thirds of S. 1 consisted either of conforming amendments that raised no substantive issues or of reenactments of existing procedural and administrative provisions. Of the remaining one-third of the bill, which deals with the new substantive penal code, by far the major part was not in dispute.

As for codification-a mere tidying-up or editorial restatement of existing law-it is enough to recall that the statute establishing the National Commission on Reform of Federal Criminal Laws called explicitly for "revision," "improvement" and "changes" such as would "better serve the ends of justice." 300 It would have been a waste of time and money to marshal the political and intellectual resources that have gone into this enterprise over the past eight years merely to restate existing law, an editorial job that the Library of Congress or any law publisher could perform satisfactorily.

A surprising aspect of the press coverage of penal reform was the extent to which journals of no marked political bent opened their news columns to handouts from the Left. A Boston Globe article reported that continued compromise efforts would cause Senator Kennedy to "lose points" with liberal supporters and that the Senator had therefore decided to withdraw his support of penal reform through amendment of S. 1. ${ }^{301}$

pinching censorship provisions, the editors gave my discussion of official secrets first place prominence. See Schwartz, A Proposal to Overhaul the Federal Criminal Laws, N.Y. Times, June 22, 1975, $\$ 4$, at 4, col. 3 .

299. See, e.g., H.R. 10612, 94th Cong., 1st Sess. (1975). The Tax Reform Act of 1976 was over 1700 pages long in the print passed by the Senate on Aug. 6, 1976. The Internal Revenue Code of 1954 (H.R. 8300) in its second reading for the Senate, March 23, 1954, consisted of 875 pages plus 418 pages of amendments.

300. See text accompanying note 13 supra.

301. Wermiel, Kennedy Pulling Back on Crime Code Bill, Boston Globe, April 21, 1976, at 2, col. 2. But cf. Editorial: Stop Stalling on S. 1, Pittsburgh Post-Gazette, Aug. 31, 1976, at 6, col. 1 (editorial in a paper which had strongly criticized S. 1 now noting that the campaign against $S$. 1 "shows signs of continuing long after the fulfillment of its basic objective, which was to strip S. 1 of questionable provisions . ..."). 
Similarly, the Detroit Free Press urged Senator Hart to "prevent a questionable compromise from being passed." 302 Harpers Magazine ran an article purporting to survey the issues raised by S. 1, apparently without consulting anybody but the violent opposition. ${ }^{303}$

There is much food for reflection here. The reasons for the media's poor performance lie deep in the structure of our society, and there is enough blame for all. Instead of blaming, however, we should ask ourselves what can be done to encourage the press to handle complex politico-legal issues so as to assist rather than preempt choices by the public. This is not the place to do more than indicate lines of action to be explored. One possibility would be for the organized bar or law teacher groups to provide a legislative analysis service of the sort that the Association of American Law Schools has provided for interpretation of Supreme Court decisions. Another alternative would be for local bar associations, guided and stimulated by the American Bar Association, to foster the flow of information from law to journalism through joint committees which would summarize and explain local and national legal developments. Law faculties could usefully collaborate with such committees.

For journalists, three innovations suggest themselves. First, a tradition of serial feature articles for handling areas of vast, perennial conflict such as criminal law, tax law, environmental law and welfare law could be developed. Second, education for journalists should include a large component of law, criminal and constitutional at least. Third, journalists' emphasis on the importance of accuracy of "facts"-propositions that can be objectively verified ${ }^{304}$-should be balanced by inculcating in them a sense of the "unknowability" of many propositions in the realm of law, economics, sociology and politics. For such areas journalists-to-be should have a mild innoculation of the lawyers' "adversary system"; that is, they should learn to tell the story less in terms of conclusions, whether of the journalist or others, than in terms of clash of evidence, logic and interest on opposing sides.

Finally, one may express the hope that general education, certainly at the college level if not in high schools, would impart sone sense of the flux, compromise and growth which are basic to democratic law. A readership so educated would demand better of the press.

302. As We See It: Phil Hart and S-1, Detroit Free Press, April 17, 1976, § A, at 6, col. 1.

303. Viorst, Nixon's Revenge: A Bill to Legalize Watergate, 252 HARPERS MAGAZINE 17 (Jan. 15, 1976).

304. One of the most baneful consequences of an undiscriminating adherence to this criterion is the tendency of some journalists to publicize a tendentious proposition by reporting "accurately" that someone, particularly an "expert," made a declaration on the subject. The important issue of the truth or falsity of the proposition gets lost under the surface truth that the declaration was made. 


\section{PROSPECTS}

The prospects are good for enacting a new federal penal code in the next several years. One may hope that the next drafters will start from the Commission Code, superimposing on it improvements developed in the course of the Senate Subcommittee's hearings and studies. Tactically, it would be well to shorten the bill drastically by separating out the substantive code for initial passage, with a proviso that it should not go into effect until after enactment of a companion bill embodying the numerous technical conforming amendments required to integrate the bill into the United States Code.

The new code will include few, if any, of the repressive features that have been identified above. It will not, of course, enact the Left's entire program. Federal law will continue to ban hard-core pornography, although federal jurisdiction may be restricted to federal enclaves, to substantial multi-state operations or to "engaging in the business" of disseminating strictly defined erotic naterials. The wiretapping law, if not dissected out of the reform project (leaving the matter to existing law and amendment by independent legislation), will probably be cut back. Capital punishment, given a new lease on life by the recent Supreme Court decisions, ${ }^{305}$ will probably be retained in some narrow applications such as killings by life prisoners, airplane hijackers or political terrorists. Handgun control will move forward another inadequate notch. The federal criminal investigative agencies may succeed in blocking the Brown Commission's innovative proposal to confine them to matters of substantial federal concern. ${ }^{306}$ The regulatory establishment zealously opposed to pollution, adulteration, untried drugs and other dangers that beset mankind but largely insensitive to abuses of criminal justice, will fight to retain criminal liability without fault and to suppress the Brown Commission's model provision for sensible restraint in criminal enforcement of administrative regulations. ${ }^{307}$ The subtle problems of justification and excuse will be sidestepped.

Despite shortcomings, enactment of the new Code would be the miracle of progress to which I referred in the opening of this Article. Criminal law would take a substantial step towards rationality and respectability. Maximum punishments would be cut back in the direction of humane and realistic limits. Penal policy would be subjected to legislative guidelines. Judicial discretion would be subject to appellate review.

305. See notes $44-45$ supra and accompanying text.

306. COMMISSION CODE $\$ 207$ (dropped in S. 1).

307. COMMISSION CODE $\S 1006$ (omitted in S. 1). The Left's proposal contains a provision making no distinction between innocent and willful violations, prescribing six months maximum imprisonment even where existing law carried a lower maximum! See H.R.10850, 94th Cong., 1st Sess. § 1304(a)(2), (a)(3) (1975) (misusing governmental authority). 
Modern definition and grading of offenses would facilitate proper law enforcement. Substituting order and system for the present chaos of overlapping, inconsistent and antiquated statutes would make it easier in the future to identify defects and make particular improvements consistent with the overall aims and capacities of the system. The federal penal law would become an influential and beneficent model for state reforms.

It is a paradox that progress will have been achieved not only despite the undiscriminating obstructionism of the Left that I have recounted, but also in part because of those deplorable tactics. Had the program of the Right gone through, as well it might have since there was so much in S. 1 that was good, the price of reform would have been too high. It is improbable that $S$. 1 could have been stopped by sweet reason in the political arena or in the press. I reluctantly confront the perennial ethical problem of good ends being served by bad means. Having nothing new to add to that endless debate, I take an existential escape: the professor's role is to speak as truly as he can. He is not responsible for enacting or blocking legislation. The civil liberties establishment, on the other hand, does have such responsibilities. Like an attorney-advocate, it need not believe in the immaculate virtue of its client. There are ethical and intellectual limits to advocacy, but the boundaries are far from precisely defined, and "[d]etached reflection cannot be demanded in the presence of an uplifted knife." 308 I shall not cancel my life-long membership in the ACLU.

One can dream of possibilities in legislation, criminal administration and political leadership that go well beyond the range of this Article. How refreshing it would be if the new President, as he signed the criminal law reform bill, should declare:

This is not a Safe Streets Act. Criminal laws are a secondary, although essential, protection against violent crime, and the states rather than the federal government are primarily responsible for physical security on the streets and in the homes. Of greater significance than criminal law, in the long run, is the confidence of all segments of the community that our system is fair and benevolent: fair in the distribution of income, fair in the assessment of taxes and other burdens, benevolent in its concern for the vital needs of every person and benevolent in its respect for individual freedom. This new federal criminal code promotes respect for law by its rationality, by its safeguards against discrimination and arbitrary punishment, and by eliminating obsolete and technical obstructions to effective law enforcement. Along with other reforms, it may make a contribution to a more tranquil life in city and countryside. We don't know that it will because, despite prodigious efforts in universities

308. Brown v. United States, 256 U.S. 335, 343 (1921) (Holmes, J.). 
and government, the causes of crime are very poorly understood and "cures" for crime virtually unknown. But if we cannot look to today's legislation to "solve the crime problem," we shall at least have cleared away ancient and ugly grievances against the system.

This modest, and therefore honest, declaration might well be accompanied by a few measures that would put future reforms on a solid footing. Among these, the highest priority might be given to establishing a credible system of criminal statistics. The existing system is a scandal..$^{309}$ It depends almost exclusively on crimes reported to the police or on arrest statistics. The very categories used in reporting crimes-larceny, robbery, burglary, fraud-embrace such a broad range of behavior, from the trivial to the most dangerous, that reporting in such categories reflects the nature and gravity of crime only with intolerable margins of error. ${ }^{310}$ Since the overwhelming majority of crimes are not reported to police, since the number of arrests made is largely a function of fluctuating police policy, and since the numbers have frequently been manipulated by reporting police departments to make themselves look better, the country is operating in a state of basic ignorance. We cannot be sure, for example, how much of the huge reported increase in crime in recent years reflects changes in the reporting system, monetary inflation that converts formerly petty thefts into reportable felonies or even such beneficent developments as a greater readiness of Blacks, emerging into the mainstream of American life, to report crimes to the police. It is time to establish a national crime census, based on scientific sampling of the general population, to ascertain the number of actual victimizations in a given period. ${ }^{311}$ Such data could be supplemented by reports from employers, insurance compamies and other institutions, and from the armed forces, regarding those vast pools of unreported theft and aggression on the docks, in the warehouses, in the banks and in department stores. It is only by regarding the phenomenon of crime with unflinching concentration and acceptance of the full truth-as if we were epidemiologists bent

309. See PRESIDENT's Commission on LAW ENFORCEMENT AND ADMINISTRATION OF JUSTICE, supra note 11, at 20-27; PRESIDENT's COMMISSION IN LAW ENFORCEMENT AND ADMINISTRATION OF JUSTICE, TASK FORCE REPORT: CRIME AND ITS IMPACT-AN ASSESSMENT 123-37 (1967).

310. A scientific approach to measuring the severity of offenses has begun. See T. SELLIN \& M. Wolfgang, The MEASURement of DeLinquency (1964); Wolfgang, Figlio \& Thornberry, Comparative Community Standards and Perceptions of Seriousness (major pending study financed by the Law Enforcement Assistance Administration).

311. Cf. PResident's Commission on Law EnForCement and Administration of Justice, supra note 11, at 20 (results of first national survey of crime victimization). See also U.S. DEP'T of Justice, LaW Enforcement Assistance Administration \& National Criminal Justice Information and Statistics Service, Criminal Victimization in the United States-A National Crime Panel Survey Report (1976) (comparison of victimization rates for 1973 and 1974). 
on wiping out smallpox in India-that we can aspire to understanding and control.

Other promising paths of advance would include: (1) providing further guidance for the exercise of judicial discretion in sentencing by developing "presumptive sentences" for typical situations, along lines recently advocated by Senators Kennedy and Hart; ${ }^{312}$ (2) creating in the Department of Justice a permanent criminal justice research unit to follow legislative, judicial and administrative developments throughout the nation and the world, and to act as a clearinghouse for information and suggestions to the states; (3) experimenting with the correctional system by, for example, making disciplined labor on public works the central experience; (4) developing some alternative to the faltering juvenile delinquency laws for removing violent young aggressives from the environments which they terrorize; and (5) introducing into the law of justification and excuse the concept of a margin for non-criminal error. ${ }^{313}$

As Mr. Justice Brandeis said long ago, "If we would guide by the light of reason, we must let our minds be bold." 314

312. S. 204, 95th Cong., 1st Sess. (1976); cf. M. FRANKEL, supra note 48, at 111-15; Twentieth Century Fund, Task Force on Criminal Sentencing, Fair and Certain PunISHMENT (1976) (directed by Prof. Alan Dershowitz); A. von HIRSCH, DoING Justice: THE ChoIce of PUNISHMENTS (Report of the Committee for the Study of Incarceration) (1976).

313. See COMmission CODE $\$ 608$ (dropped in S. 1 \$ 211 ). Under present law, for example, a person who would have been justified in shooting in self-defense or shooting a nighttime intruder may be convicted of criminal homicide if he was marginally hasty or marginally "unreasonable" in his appraisal of the situation. Such a legal arrangement makes the difference between heroism and criminality paper-thin. The criminal law is more properly reserved for egregious misbehavior. Compare the difference between negligence for purposes of tort recovery and "criminal negligence," or between civil and criminal fraud. That principle of frugality in the use of criminal sanctions is as apt on the justification issues as it is on the prohibition issues.

314. New State Ice Co. v. Liebmann, 285 U.S. 262, 311 (1932) (Brandeis, J., dissenting). 